\title{
The Role of Phosphorus Slag in Steam-Cured Concrete
}

\author{
Jin Liu and Dongmin Wang \\ School of Chemical and Environmental Engineering, China University of Mining and Technology, Beijing 100083, China \\ Correspondence should be addressed to Dongmin Wang; wangdongmin-2008@163.com
}

Received 12 March 2017; Accepted 22 March 2017; Published 24 April 2017

Academic Editor: Xiao-Jian Gao

Copyright (C) 2017 Jin Liu and Dongmin Wang. This is an open access article distributed under the Creative Commons Attribution License, which permits unrestricted use, distribution, and reproduction in any medium, provided the original work is properly cited.

\begin{abstract}
Steam curing is an effective method to increase the hydration degree of binder containing phosphorus slag. The role of phosphorus slag in steam-cured concrete was investigated by determining the hydration heat, hydration products, nonevaporable water content, pore structure of paste, and the compressive strength and chloride ion permeability of concrete. The results show that elevated steam curing temperature does not lead to new crystalline hydration products of the composite binder containing phosphorus slag. Elevating steam curing temperature enhances the early hydration heat and nonevaporable water content of the binder containing phosphorus slag more significantly than increasing steam curing time, and it also results in higher late-age hydration degree and finer pore structure. For steam-cured concrete containing phosphorus slag, elevating curing temperature from $60^{\circ} \mathrm{C}$ to $80^{\circ} \mathrm{C}$ tends to decrease the late-age strength and increase the chloride permeability. However, at constant curing temperature of $60^{\circ} \mathrm{C}$, the steam-cured concrete containing phosphorus slag can achieve satisfied demoulding strength and late-age strength and chloride permeability by extending the steam curing duration.
\end{abstract}

\section{Introduction}

With the development of the construction of concrete engineering, an increasing number of precast concrete elements are applied to modern architectures. Compared with pumping concrete, precast concrete has many advantages, such as more efficient manufacture process, more stable quality, shorter building time, lower cost, and safer and cleaner environment of construction [1-4]. Steam curing is the most popular method in the production of precast concrete elements, which makes great contribution to construction industrialization $[5,6]$. The pressure of steam curing includes high pressure, normal atmospheric pressure, and no pressure [7]. Due to economic consideration, steam curing with normal atmospheric pressure is widely used. Presetting period, heating up period, constant temperature period, and cooling period constitute a steam curing process $[8,9]$. The temperature of constant period is one of the most important parameters of steam curing regimes, which is usually at $40 \sim 90^{\circ} \mathrm{C}$ [10-14]. It is notable that steam-cured concrete normally has a high permeability and a low strength gain rate at late ages due to the nonuniformly distributed hydration products and loose pore structure of paste caused by high curing temperature [15-18].

Mineral admixtures such as fly ash and ground granulated blast furnace slag (GGBS) are widely used in modern concrete. Application of mineral admixtures to concrete might improve workability of fresh concrete, reduce hydration heat of cement, and enhance late strength and durability of concrete at late ages. The traditional mineral admixtures are becoming increasing scarce, so new kinds of mineral admixtures such as steel slag, limestone powder, and phosphorus slag are gradually used in concrete production [1921]. Phosphorus slag is a by-product in the production of yellow phosphorus by electric furnace method in industry. It is reported that about 8 to 10 tons of phosphorus slag are produced for 1 ton of yellow phosphorus production [22]. More than 8 million tons of phosphorus slag are generated every year in China and the utilization ratio is very low [23]. The major chemical compositions of phosphorus slag are $\mathrm{CaO}$ and $\mathrm{SiO}_{2}$, which normally accounts for over $80 \%$ [24]. Based on different nature of phosphate ores, the minor compositions of phosphorus slag are 2.5 5\% $\mathrm{Al}_{2} \mathrm{O}_{3}, 1 \sim 5 \%$ $\mathrm{P}_{2} \mathrm{O}_{5}, 0.5 \sim 3 \% \mathrm{MgO}, 0.2 \sim 2.5 \% \mathrm{Fe}_{2} \mathrm{O}_{3}$, and 0 2.5\% F [25]. 
TABLE 1: The chemical compositions of the raw materials\%.

\begin{tabular}{lcccccccccc}
\hline Sample & $\mathrm{SiO}_{2}$ & $\mathrm{Al}_{2} \mathrm{O}_{3}$ & $\mathrm{Fe}_{2} \mathrm{O}_{3}$ & $\mathrm{CaO}$ & $\mathrm{MgO}$ & $\mathrm{SO}_{3}$ & $\mathrm{Na}_{2} \mathrm{O}_{\text {eq }}$ & Loss & $\mathrm{P}_{2} \mathrm{O}_{5}$ & $\mathrm{~F}$ \\
\hline Cement & 22.36 & 7.73 & 3.66 & 57.21 & 3.10 & 3.54 & 0.73 & 2.31 & - & - \\
Phosphorus slag & 38.27 & 5.33 & 0.29 & 43.12 & 1.69 & 1.30 & 1.75 & 2.16 & 4.62 & 2.46 \\
\hline
\end{tabular}

Note. $\mathrm{Na}_{2} \mathrm{O}_{\mathrm{eq}}=\mathrm{Na}_{2} \mathrm{O}+0.685 \mathrm{~K}_{2} \mathrm{O}$.

Researches showed that phosphorus slag could refine the lateage pore structure of hardened paste, reduce early hydration heat of cement, and enhance durability of concrete [26, 27]. It is well accepted that phosphorus slag has a strong retarding effect on the early hydration of cement [28-30]. The concrete incorporating phosphorus slag achieves very low early strength, so the application of phosphorus slag to concrete is restricted to a certain extent.

Due to low reactivity or lack of sufficient alkali activation, mineral admixtures usually exhibit a low reaction degree at early ages [31,32]. Correspondingly, the concrete containing mineral admixtures usually achieves a lower early strength compared with the plain cement concrete [33, 34]. However, the hydration degree of mineral admixtures increases significantly with the increase of curing temperature and steam curing time at early ages, which contributes to the strength development of concrete [35-38]. Therefore, steam curing is an effective method to improve the strength of concrete containing mineral admixtures at early ages [39-41]. It is a potential method to improve the late-age pore structure of steam-cured concrete by using mineral admixture.

In this paper, phosphorus slag was used in steam-cured concrete. In order to enhance the demoulding strength of steam-cured concrete containing phosphorus slag, two methods were employed: increasing the steam curing temperature and extending the steam curing duration. The effects of these two methods on the properties of steam-cured concrete containing phosphorus slag were compared.

\section{Raw Materials and Test Methods}

2.1. Raw Materials. The cement used was Ordinary Portland cement with the specific surface area of $350 \mathrm{~m}^{2} \mathrm{~kg}^{-1}$ and the strength grade of 42.5 complying with the Chinese National Standard GB175-2007. The chemical compositions of the cement and the phosphorus slag are provided in Table 1. Figure 1 shows the scanning electron microscope (SEM) image of phosphorus slag, which indicates that the particles of phosphorus slag have an irregular shaped morphology. Figure 2 shows the XRD patterns of the phosphorus slag, which indicates that most of the mineral phases of the phosphorus slag are amorphous. The particle size distributions of the cement and the phosphorus slag are shown in Figure 3. Coarse and fine aggregates were crushed limestone between $5 \mathrm{~mm}$ and $25 \mathrm{~mm}$ and natural river sand smaller than $5 \mathrm{~mm}$, respectively.

2.2. Test Methods. Table 2 lists the mix proportions of concrete. Concrete $\mathrm{C}$ and concrete $\mathrm{CC}$ were plain cement concrete with the water-to-binder ratios (W/B) of 0.4 and 0.32 , respectively. Concrete $\mathrm{N} 1$ and concrete $\mathrm{NN} 1$ were the

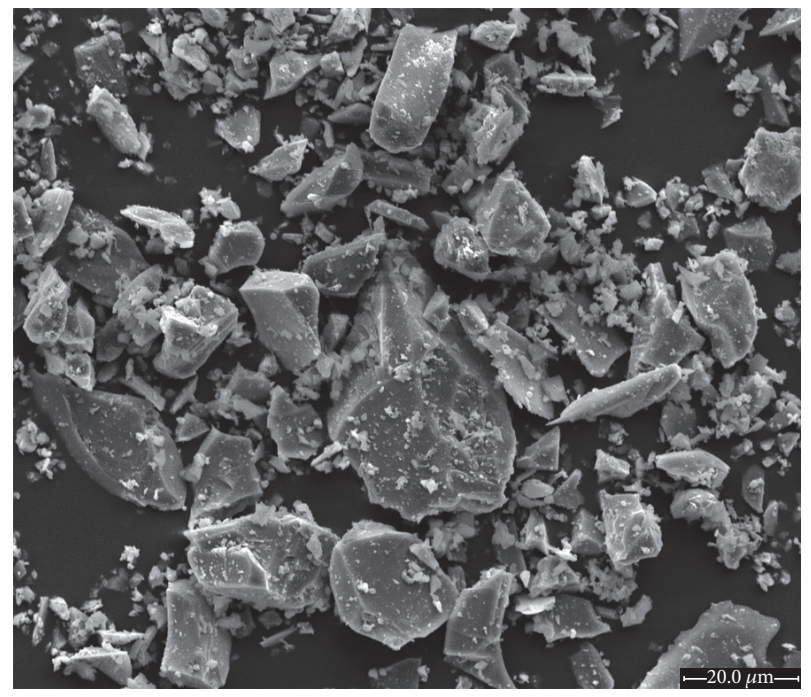

FIGURE 1: Scanning electron microscope image of the phosphorus slag.

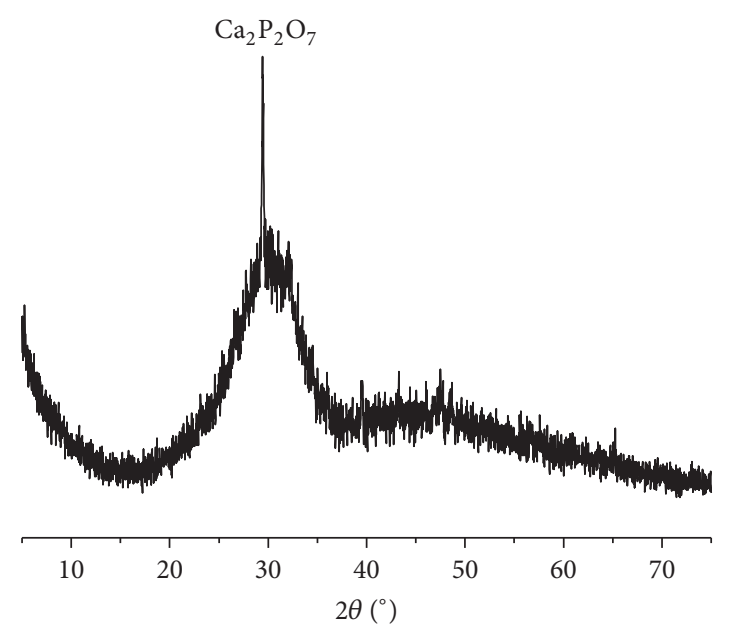

FIGURE 2: XRD pattern of the phosphorus slag.

ones containing $15 \%$ phosphorus slag with the W/B of 0.4 and 0.32 , respectively. Concrete $\mathrm{N} 2$ and concrete NN2 were the ones containing $30 \%$ phosphorus slag with the W/B of 0.4 and 0.32 , respectively. Table 3 lists the mix proportions of pastes. The composition of binder and $\mathrm{W} / \mathrm{B}$ of the pastes corresponds to those of the concrete.

Two curing methods for the concrete were set in this study: (1) standard curing: concrete was cured in a room with a temperature of $20 \pm 1^{\circ} \mathrm{C}$ and a relative humidity higher 
TABLE 2: Mix proportions of concrete $/ \mathrm{kg} \cdot \mathrm{m}^{-3}$.

\begin{tabular}{lccccc}
\hline Sample & Cement & Phosphorus slag & Sand & Stone & Water \\
\hline C & 380 & 0 & 785 & 785 & 1083 \\
N1 & 323 & 57 & 785 & 1083 & 152 \\
N2 & 266 & 114 & 780 & 1083 & 152 \\
CC & 450 & 0 & 780 & 1076 & 1076 \\
NN1 & 382.5 & 67.5 & 780 & 144 \\
NN2 & 315 & 135 & & 144 \\
\hline
\end{tabular}

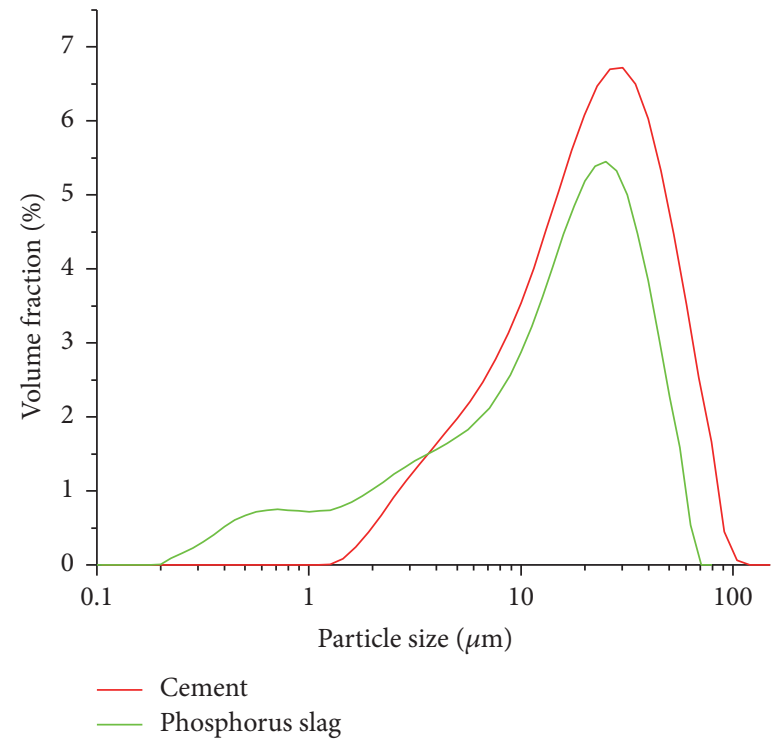

FIgURe 3: Particle size distributions of the cement and the phosphorus slag.

TABLE 3: Mix proportions of pastes/g.

\begin{tabular}{lccc}
\hline Sample & Cement & Phosphorus slag & Water \\
\hline C & 100 & 0 & 40 \\
N1 & 85 & 15 & 40 \\
N2 & 70 & 30 & 40 \\
CC & 100 & 0 & 32 \\
NN1 & 85 & 15 & 32 \\
NN2 & 70 & 30 & 32 \\
\hline
\end{tabular}

than 95\% and (2) steam curing: the concrete was placed in a standard curing room for a precuring period of $3 \mathrm{~h}$ after casting and then cured in a curing box. For plain cement concrete, the temperature of the constant period was $60^{\circ} \mathrm{C}$ and duration of constant period was $8 \mathrm{~h}$. For the concrete containing phosphorus slag, duration of constant period was extended to $11 \mathrm{~h}$ when the temperature of the constant period was $60^{\circ} \mathrm{C}$, and the temperature of the constant period was increased to $80^{\circ} \mathrm{C}$ when the duration of constant period was $8 \mathrm{~h}$. Both of the times for heating up period and cooling period were $2 \mathrm{~h}$. The concrete was placed in the standard curing room after steam curing.
Concrete of $100 \times 100 \times 100 \mathrm{~mm}$ was cast. The compressive strength of concrete was tested at the ages of demoulding time, $3 \mathrm{~d}, 28 \mathrm{~d}$, and $90 \mathrm{~d}$. For the concrete cured under standard condition, the demoulding time was $18 \mathrm{~h}$. The chloride ion permeability of concrete was tested at the ages of $28 \mathrm{~d}$ and $90 \mathrm{~d}$. The chloride ion permeability was evaluated by measuring the charge passed of concrete according to ASTM C 1202 "Standard Test Method for Electrical Indication of Concrete's Ability to Resist Chloride Ion Penetration."

The pastes were cast in plastic sealed tubes after preparation and cured under the same conditions with concrete. Hardened pastes were extracted and then immersed into absolute alcohol to prevent further hydration at testing ages. The pore characteristics of pastes were determined by mercury intrusion porosimetry (MIP). X-ray diffraction (XRD) was used to determine the mineral phases of hydration products. The nonevaporable water $\left(w_{n}\right)$ content of paste was calculated as the mass difference between the samples dried at $105^{\circ} \mathrm{C}$ and heated at $1000^{\circ} \mathrm{C}$ normalized by the mass after being dried at $105^{\circ} \mathrm{C}$ and correcting for the loss on ignition of unhydrated samples [42]. The hydration heat evolution of the binder at the W/B of 0.4 and 0.32 within $24 \mathrm{~h}$ was tested by using an isothermal calorimeter at constant temperatures of $60^{\circ} \mathrm{C}$ and $80^{\circ} \mathrm{C}$, respectively.

The temperature of constant period is denoted with suffix "-60" or "-80." Additionally, the time of constant period is denoted with suffix "-8" or "-11." For example, "C-60-8" represents the sample $\mathrm{C}$ cured at $60^{\circ} \mathrm{C}$ for $8 \mathrm{~h}$.

\section{Results and Discussion}

3.1. Hydration Heat. Figure 4(a) shows the exothermic rates during the hydration of samples $\mathrm{C}, \mathrm{N} 1$, and $\mathrm{N} 2$ at $60^{\circ} \mathrm{C}$ within $24 \mathrm{~h}$. At $\mathrm{W} / \mathrm{B}$ of 0.4 , with the increase of phosphorus slag addition, the dormant period of binder is prolonged. In addition, the exothermic peak of binder is postponed and the exothermic peak value of binder decreases. These results indicate that the addition of phosphorus slag tends to decrease the exothermic rate of binder at early ages. Figure 4(b) shows the exothermic rates during the hydration of samples CC, NN1, and NN2 at $60^{\circ} \mathrm{C}$ within $24 \mathrm{~h}$. At W/B of 0.32 , the influence of phosphorus slag on the exothermic rate of binder is basically the same with that of binder at W/B of 0.4 .

Figures 5(a) and 5(b) show the exothermic rates during the hydration of samples $\mathrm{C}, \mathrm{N} 1$, and $\mathrm{N} 2$ as well as samples CC, $\mathrm{NN} 1$, and $\mathrm{NN} 2$ at $80^{\circ} \mathrm{C}$ within $24 \mathrm{~h}$, respectively. When the 


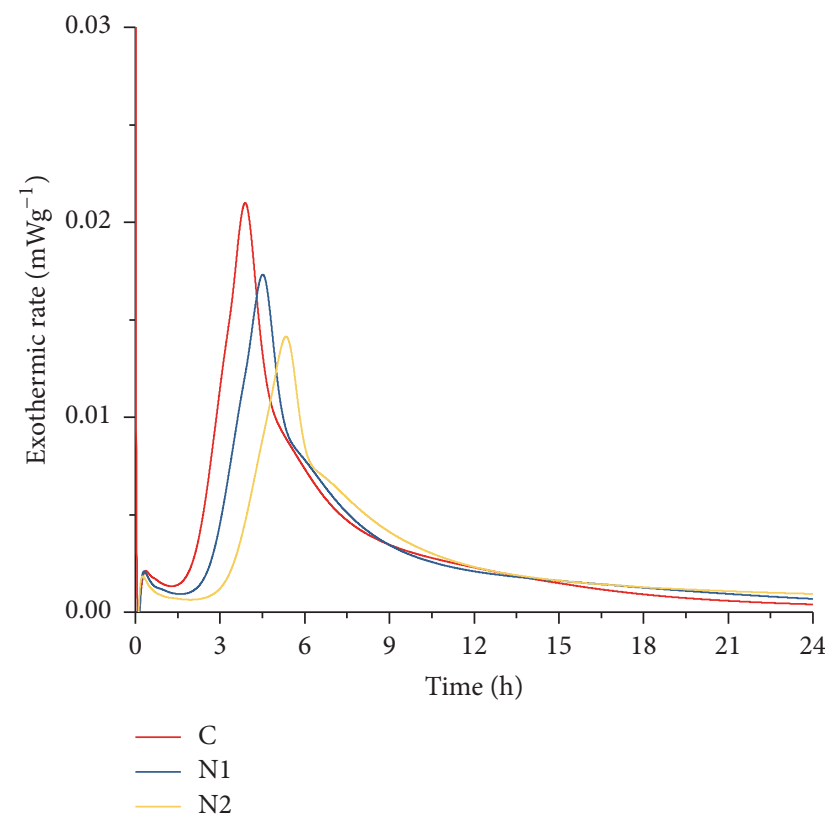

(a)

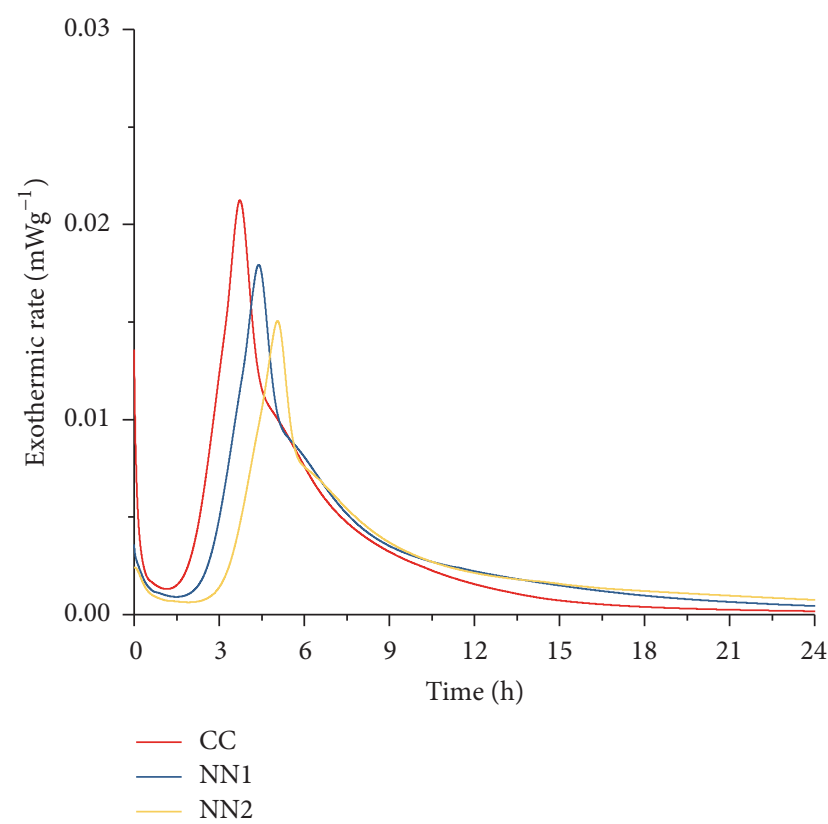

(b)

Figure 4: (a) Exothermic rates during the hydration of samples C, N1, and N2 at $60^{\circ} \mathrm{C}$. (b) Exothermic rates during the hydration of samples $\mathrm{CC}, \mathrm{NN} 1$, and $\mathrm{NN} 2$ at $60^{\circ} \mathrm{C}$.

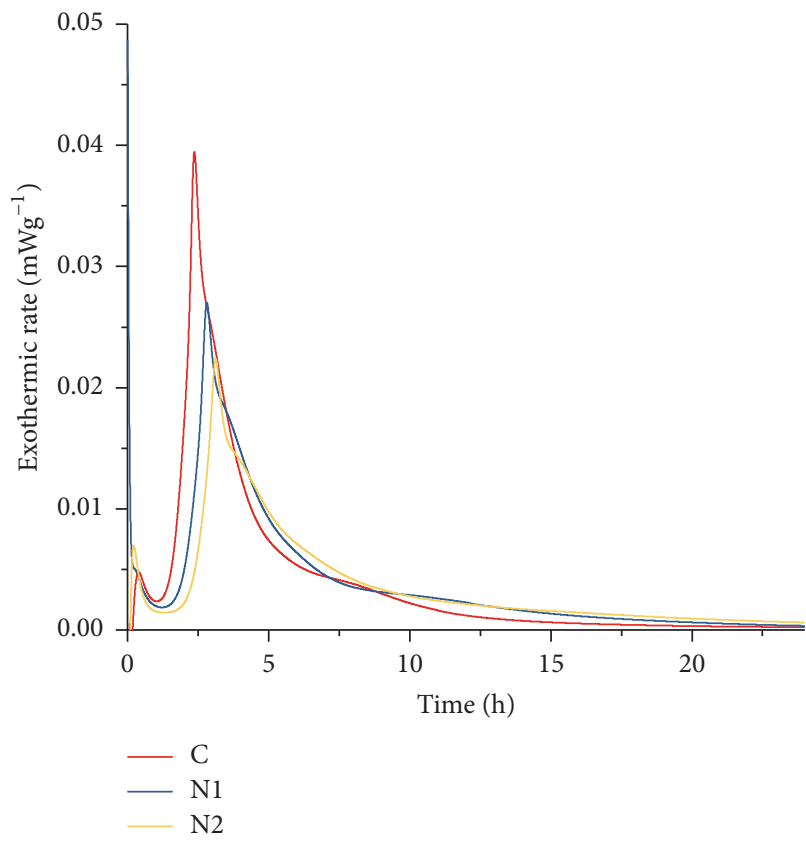

(a)

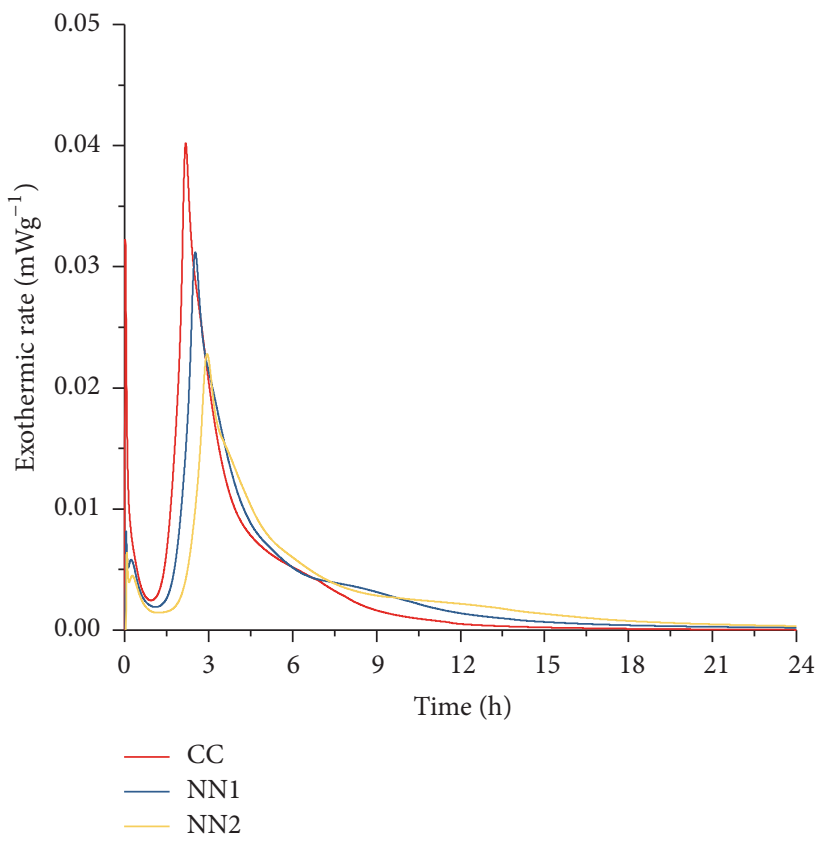

(b)

Figure 5: (a) Exothermic rates during the hydration of samples C, N1, and $\mathrm{N} 2$ at $80^{\circ} \mathrm{C}$. (b) Exothermic rates during the hydration of samples $\mathrm{CC}, \mathrm{NN} 1$, and $\mathrm{NN} 2$ at $80^{\circ} \mathrm{C}$.

temperature is elevated from $60^{\circ} \mathrm{C}$ to $80^{\circ} \mathrm{C}$, the exothermic peak of binder occurs earlier and the exothermic peak value of binder increases. These results indicate that the exothermic rate of binder increases significantly with an elevated temperature from $60^{\circ} \mathrm{C}$ to $80^{\circ} \mathrm{C}$. What is more, the addition of phosphorus slag also tends to decrease the exothermic rate of binder at early ages at $80^{\circ} \mathrm{C}$.

The accumulative hydration heats of the plain cement and the binders containing phosphorus slag are shown in Table 4. At W/B of 0.4 , under constant temperature of 
TABLE 4: Accumulative hydration heats of the plain cement and the binders containing phosphorus slag $\left(\mathrm{J} \cdot \mathrm{g}^{-1}\right)$.

\begin{tabular}{|c|c|c|c|}
\hline \multirow{2}{*}{ Sample } & \multicolumn{2}{|c|}{$60^{\circ} \mathrm{C}$} & \multirow{2}{*}{$\begin{array}{c}80^{\circ} \mathrm{C} \\
8 \mathrm{~h} \\
\end{array}$} \\
\hline & $8 \mathrm{~h}$ & $11 \mathrm{~h}$ & \\
\hline $\mathrm{C}$ & 222.1 & 257.3 & 288.5 \\
\hline N1 & 183.3 & 217.8 & 258.2 \\
\hline N2 & 141 & 181.9 & 210.6 \\
\hline CC & 230.6 & 262.2 & 290.6 \\
\hline NN1 & 189.2 & 224.7 & 248.2 \\
\hline NN2 & 148.4 & 185.2 & 207.8 \\
\hline
\end{tabular}

$60^{\circ} \mathrm{C}$, the increase ratios of accumulative hydration heats of samples C, N1, and N2 are $15.8 \%, 18.8 \%$, and $29.0 \%$ by increasing curing time from $8 \mathrm{~h}$ to $11 \mathrm{~h}$, respectively. At constant curing time of $8 \mathrm{~h}$, the increase ratios of accumulative hydration heats of samples $\mathrm{C}, \mathrm{N} 1$, and $\mathrm{N} 2$ are $29.9 \%, 40.9 \%$, and $49.4 \%$ by increasing curing temperature from $60^{\circ} \mathrm{C}$ to $80^{\circ} \mathrm{C}$, respectively. These results indicate that both extended duration and elevated temperature promote the hydration degree of cement and the binders containing phosphorus slag significantly, but the promoting effect of elevated temperature is greater. What is more, the promoting effect of extended duration and elevated temperature on hydration degree of the binders containing phosphorus slag is greater at higher phosphorus slag replacement. This is because both the hydration of cement and reaction of phosphorus slag are promoted in the composite binder and the reaction degree of phosphorus slag is promoted more significantly than the hydration degree of cement. At W/B of 0.32 , under constant temperature of $60^{\circ} \mathrm{C}$, the increase ratios of accumulative hydration heats of samples CC, NN1, and $\mathrm{NN} 2$ are $13.7 \%, 18.8 \%$, and $24.8 \%$ by increasing curing time from $8 \mathrm{~h}$ to $11 \mathrm{~h}$, respectively. At constant curing time of $8 \mathrm{~h}$, the increase ratios of accumulative hydration heats of samples CC, $\mathrm{NN} 1$, and $\mathrm{NN} 2$ are $26.0 \%, 31.2 \%$, and $40.0 \%$ by increasing curing temperature from $60^{\circ} \mathrm{C}$ to $80^{\circ} \mathrm{C}$, respectively. The influence of extended duration and elevated temperature on hydration degree of plain cement and the binders containing phosphorus slag is basically the same with that of binder at $\mathrm{W} / \mathrm{B}$ of 0.4 .

3.2. $X R D$ Results. Figure 6 shows the XRD results of the plain cement paste and the paste containing $30 \%$ phosphorus slag under the standard curing condition at the age of $90 \mathrm{~d}$. The XRD pattern only displays the crystalline phases in the hydration products of the binder. However, gel is amorphous and therefore the characteristic peak of gel cannot be found in the XRD pattern. It can be seen that the angle positions of the characteristic peaks of two kind of pastes are identical at the age of $90 \mathrm{~d}$. This indicates that there is no new crystalline substance in the hydration products of the composite binder containing phosphorus slag, and the reaction products of phosphorus slag are amorphous gel. Figure 7 shows the XRD results of the paste containing 30\% phosphorus slag under different curing temperatures at the age of $90 \mathrm{~d}$. It can be seen that the angle positions of the characteristic peaks of the pastes containing $30 \%$ phosphorus slag under different

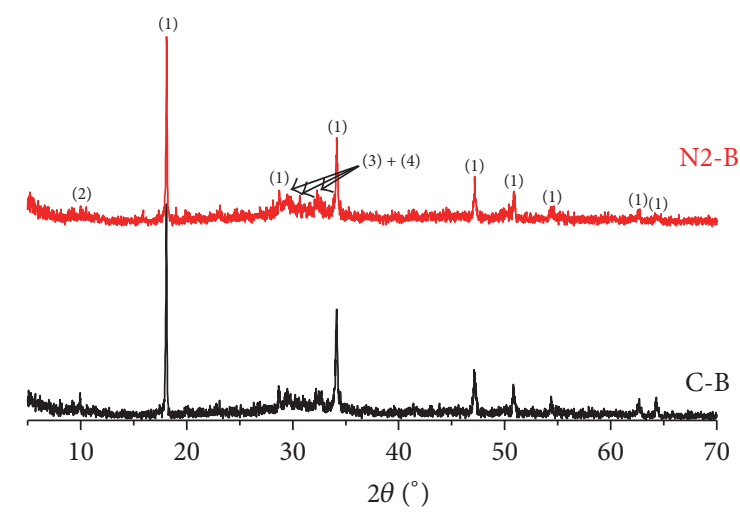
(1) $\mathrm{Ca}(\mathrm{OH})_{2}$
(3) $\mathrm{C}_{3} \mathrm{~S}$
(2) AFm
(4) $\mathrm{C}_{2} \mathrm{~S}$

FIGURE 6: XRD patterns of the standard-cured paste at the age of $90 \mathrm{~d}$.

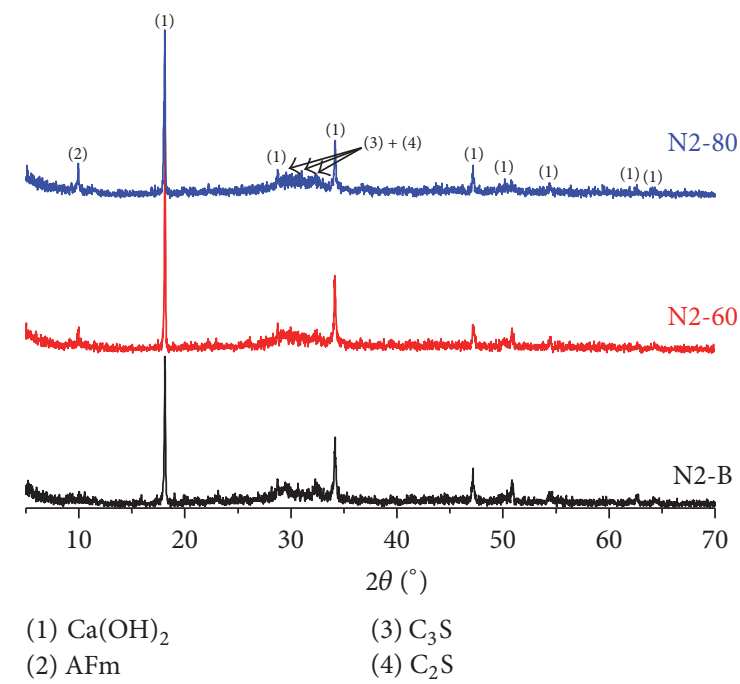

FIGURE 7: XRD patterns of the paste containing phosphorus slag at the age of $90 \mathrm{~d}$.

steam curing temperatures at the age of $90 \mathrm{~d}$ are identical. This indicates that elevated steam curing temperature does not lead to new crystalline hydration products of the composite binder containing phosphorus slag.

3.3. Nonevaporable Water Content. The nonevaporable water $\left(w_{n}\right)$ content represents the amount of hydration products. The $w_{n}$ content can be used to determine the hydration degree of binder. Figures 8 and 9 show the $w_{n}$ contents of the pastes containing phosphorus slag with $\mathrm{W} / \mathrm{B}$ of 0.4 and 0.32 at the age of demoulding time, respectively. It is clear that the $w_{n}$ contents of the pastes containing phosphorus slag under the steam curing of $60^{\circ} \mathrm{C}$ for $11 \mathrm{~h}$ and $80^{\circ} \mathrm{C}$ for $8 \mathrm{~h}$ are significantly higher than that under standard curing at the age of demoulding time. It is believed that elevated temperature accelerates the hydration of cement as well as the reaction of phosphorus slag. Meanwhile, the increased amplitude of the $w_{n}$ content of each sample under the steam curing of $80^{\circ} \mathrm{C}$ 


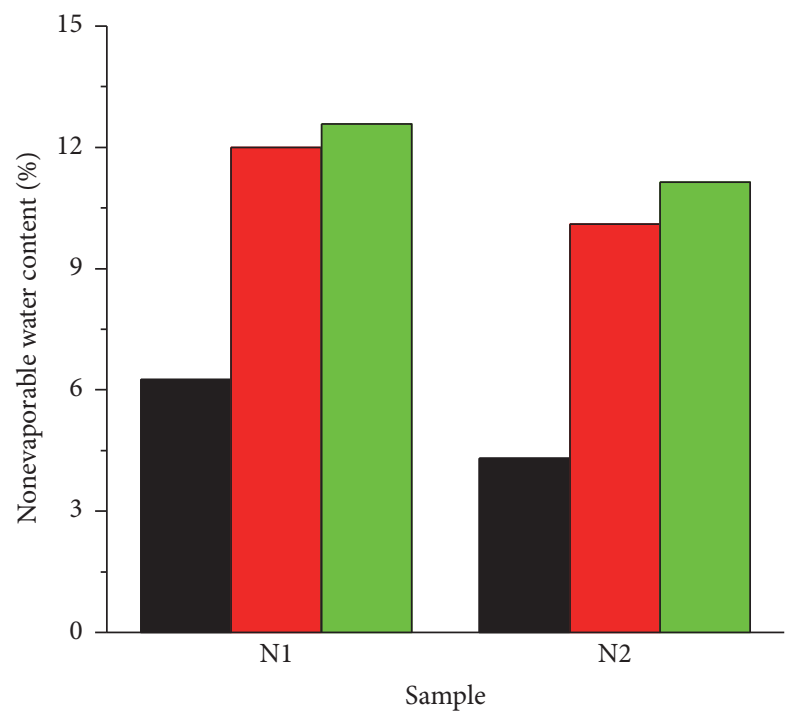

Standard curing
At $60^{\circ} \mathrm{C}$ for $11 \mathrm{~h}$
At $80^{\circ} \mathrm{C}$ for $8 \mathrm{~h}$

FIGURE 8: Nonevaporable water contents of the pastes containing phosphorus slag with $\mathrm{W} / \mathrm{B}$ of 0.4 at the age of demoulding time.

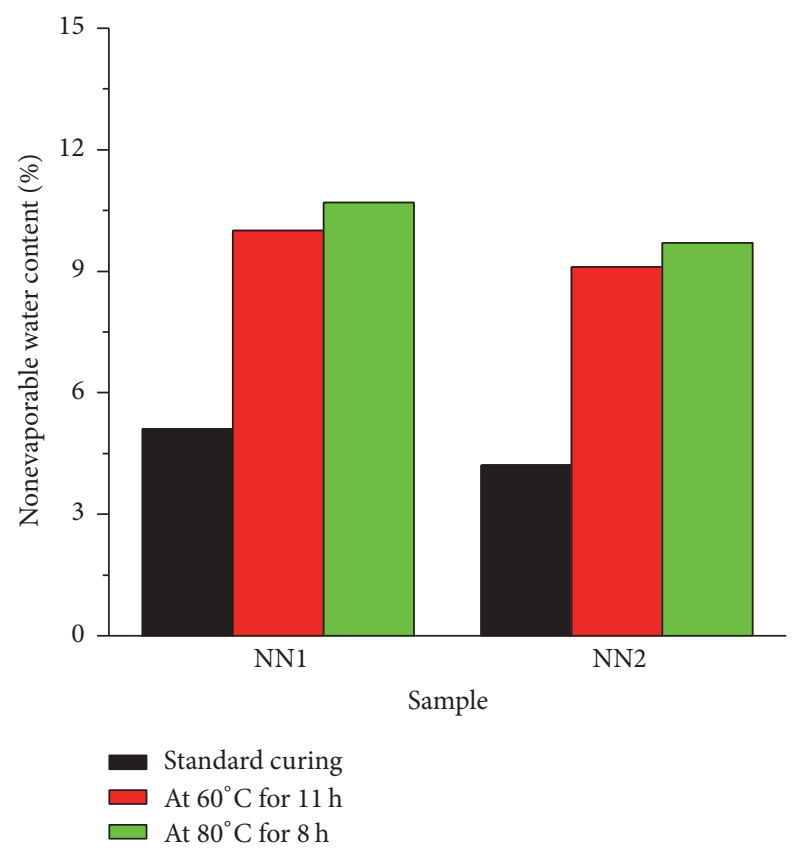

FIGURE 9: Nonevaporable water contents of the pastes containing phosphorus slag with $\mathrm{W} / \mathrm{B}$ of 0.32 at the age of demoulding time.

for $8 \mathrm{~h}$ is larger than that under the steam curing of $60^{\circ} \mathrm{C}$ for $11 \mathrm{~h}$. This indicates that elevated curing temperature tends to accelerate the early hydration rate of the binder containing phosphorus slag more effectively than extended steam curing duration.

Figures 10 and 11 show the $w_{n}$ contents of the paste containing phosphorus slag with $\mathrm{W} / \mathrm{B}$ of 0.4 and 0.32 at

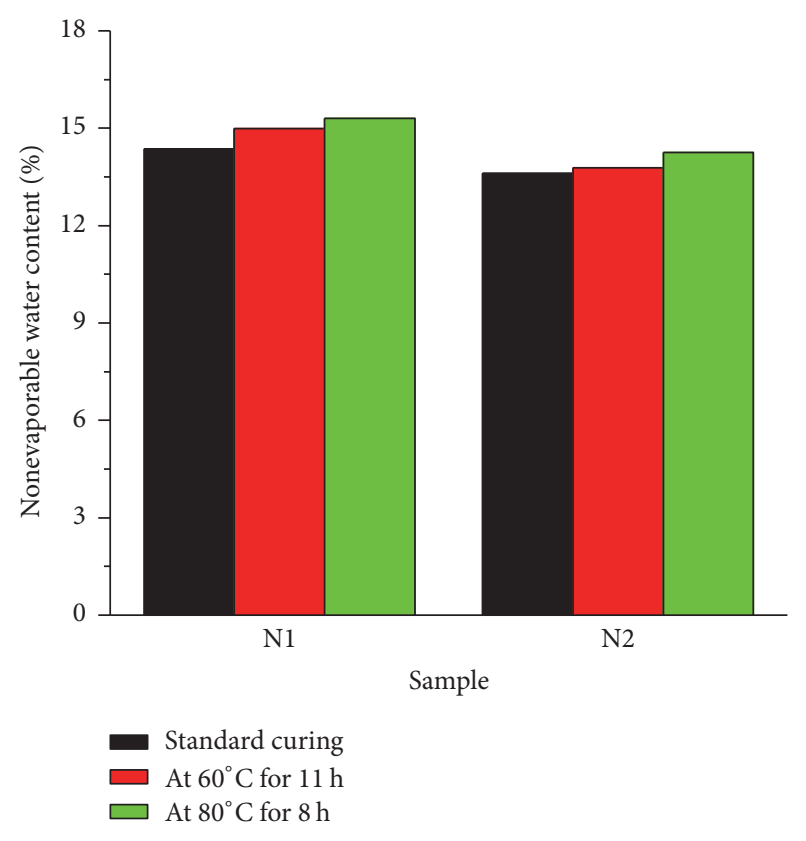

FIGURE 10: Nonevaporable water contents of the pastes containing phosphorus slag with W/B of 0.4 at the age of $90 \mathrm{~d}$.

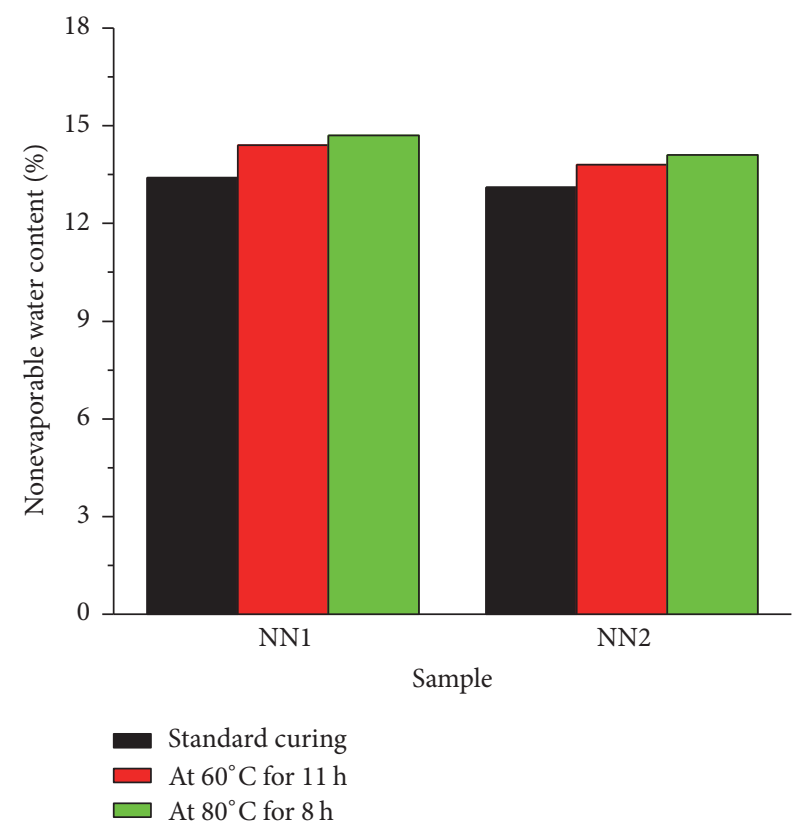

FIGURE 11: Nonevaporable water contents of the pastes containing phosphorus slag with $\mathrm{W} / \mathrm{B}$ of 0.32 at the age of $90 \mathrm{~d}$.

the age of $90 \mathrm{~d}$, respectively. In general, dense and thick $\mathrm{C}-\mathrm{S}-\mathrm{H}$ layer grows around cement grains if the binder is cured under high temperature at early ages, which tends to hinder the hydration of cement at late ages [43]. However, it is interesting to find that the $w_{n}$ contents of the pastes containing phosphorus slag under the curing condition of $60^{\circ} \mathrm{C}$ for $11 \mathrm{~h}$ and $80^{\circ} \mathrm{C}$ for $8 \mathrm{~h}$ are also a little higher than that 


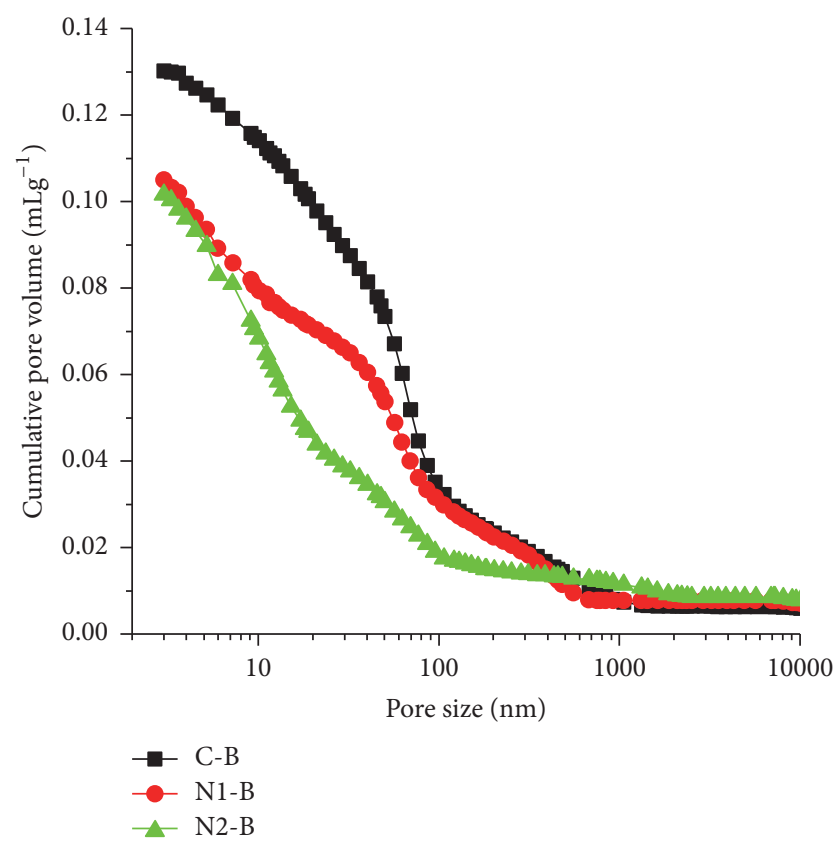

FIgURE 12: Pore structures of the standard-cured hardened paste with $\mathrm{W} / \mathrm{B}$ of 0.4 at the age of $90 \mathrm{~d}$.

under standard curing at the age of $90 \mathrm{~d}$. The reasons may be as follows: (1) the sample experienced a precuring period of $3 \mathrm{~h}$ and the duration of the steam curing is not longer than $11 \mathrm{~h}$, so the adverse effect of elevated temperature on the late hydration is not so obvious; (2) an elevated steam curing temperature promotes the reaction degree of phosphorus slag resulting in more reaction products. In addition, the $w_{n}$ content of the paste containing phosphorus slag under the steam curing of $80^{\circ} \mathrm{C}$ for $8 \mathrm{~h}$ is higher than that under the steam curing of $60^{\circ} \mathrm{C}$ for $11 \mathrm{~h}$ at the age of $90 \mathrm{~d}$. This is probably due to the fact that an elevated steam curing temperature tends to promote the reaction degree of phosphorus slag more significantly than an extended steam curing duration.

It can be concluded from Figures $8-11$ that the $w_{n}$ content of the paste containing phosphorus slag under the steam curing of $80^{\circ} \mathrm{C}$ for $8 \mathrm{~h}$ is higher than that under the steam curing of $60^{\circ} \mathrm{C}$ for $11 \mathrm{~h}$ at the ages of demoulding time as well as $90 \mathrm{~d}$. The influences of elevating curing temperature and increasing curing time on the early nonevaporable water content of the paste containing phosphorus slag are consistent with those on the early hydration heats of the binder containing phosphorus slag.

3.4. Pore Structure. The pore size distributions of the standard-cured hardened pastes with $\mathrm{W} / \mathrm{B}$ of 0.4 and 0.32 at the age of $90 \mathrm{~d}$ are depicted in Figures 12 and 13, respectively. For the samples with $\mathrm{W} / \mathrm{B}$ of 0.4 , it is evident that the cumulative pore volume of the hardened paste containing $15 \%$ phosphorus slag is lower than that of the hardened plain cement paste. Both the cumulative pore volume and the proportion of pores larger than $100 \mathrm{~nm}$ of the hardened paste containing 30\% phosphorus slag are lower than that of the plain cement paste. For samples with W/B of 0.32 ,

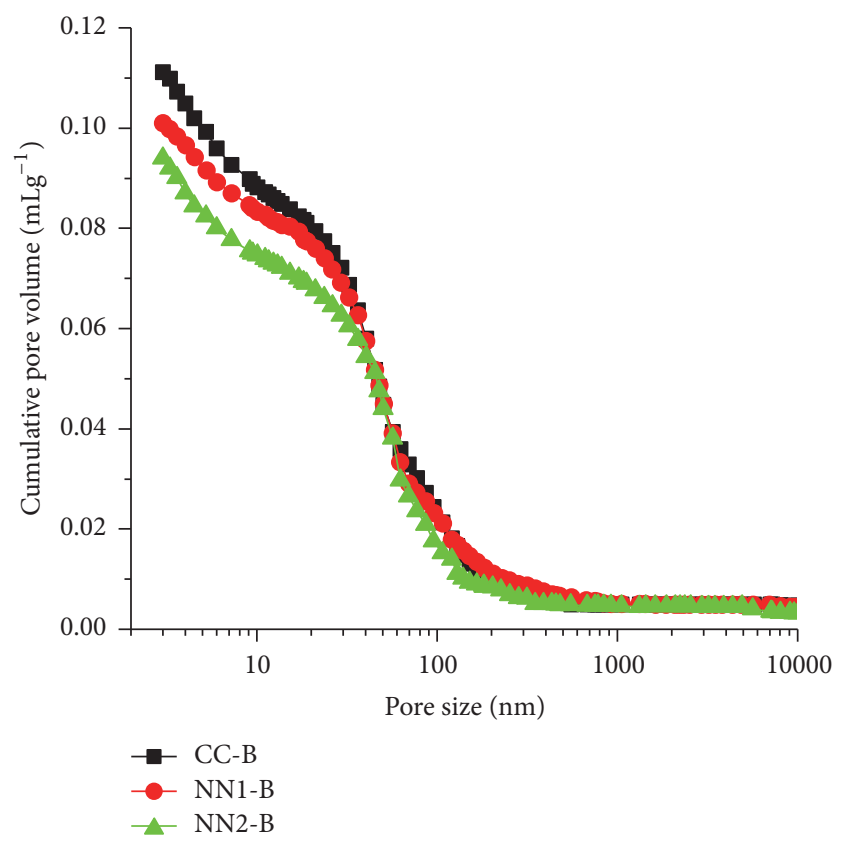

FIGURE 13: Pore structures of the standard-cured hardened paste with $\mathrm{W} / \mathrm{B}$ of 0.32 at the age of $90 \mathrm{~d}$.

the cumulative pore volume decreases with the increase of phosphorus slag addition. However, at such a low W/B of 0.32 , though the addition of phosphorus slag tends to reduce porosity, its influence on the pore structure is limited to some extent. In conclusion, the addition of phosphorus slag can optimize the pore structure of hardened paste under standard curing condition, and the optimization effect becomes more obvious with the increase of the replacement ratio of phosphorus slag within the replacement limit of $30 \%$.

The pore size distributions of the steam-cured hardened pastes with W/B of 0.4 at the age of $90 \mathrm{~d}$ are depicted in Figure 14. The hardened plain cement paste cured at $60^{\circ} \mathrm{C}$ for $8 \mathrm{~h}$ is employed as the control group. It is clear that both the cumulative pore volume and the proportion of pores larger than $100 \mathrm{~nm}$ of the hardened pastes containing phosphorus slag under the steam curing of $60^{\circ} \mathrm{C}$ for $11 \mathrm{~h}$ and $80^{\circ} \mathrm{C}$ for $8 \mathrm{~h}$ are lower than those of control group. Meanwhile, both the cumulative pore volume and the proportion of pores larger than $100 \mathrm{~nm}$ of the hardened pastes containing phosphorus slag under the steam curing of $80^{\circ} \mathrm{C}$ for $8 \mathrm{~h}$ are the least, which indicates that elevated curing temperature tends to optimize the late-age pore structure of the hardened paste containing phosphorus slag more effectively than extended steam curing duration.

The pore size distributions of the steam-cured hardened pastes with $\mathrm{W} / \mathrm{B}$ of 0.32 at $90 \mathrm{~d}$ are depicted in Figure 15. It is clear that both the cumulative pore volume and the proportion of pores larger than $100 \mathrm{~nm}$ of the hardened pastes containing phosphorus slag under the steam curing of $60^{\circ} \mathrm{C}$ for $11 \mathrm{~h}$ are lower than those of control group. The proportion of pores larger than $100 \mathrm{~nm}$ of the hardened paste containing phosphorus slag under the steam curing of $80^{\circ} \mathrm{C}$ for $8 \mathrm{~h}$ 


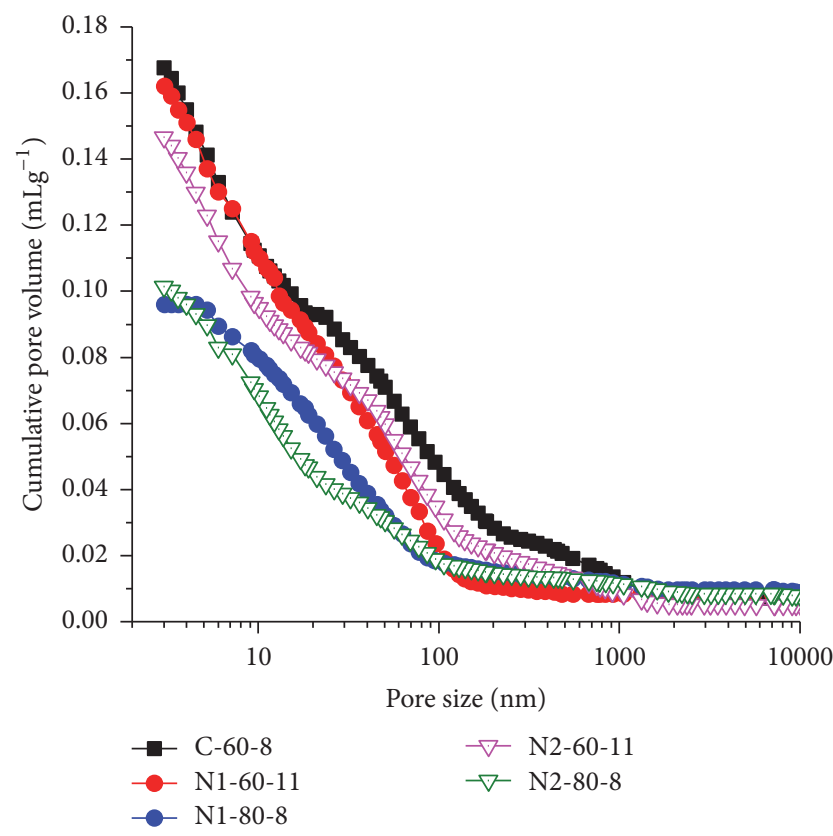

FIGURE 14: Pore structures of the steam-cured hardened paste with $\mathrm{W} / \mathrm{B}$ of 0.4 at the age of $90 \mathrm{~d}$.

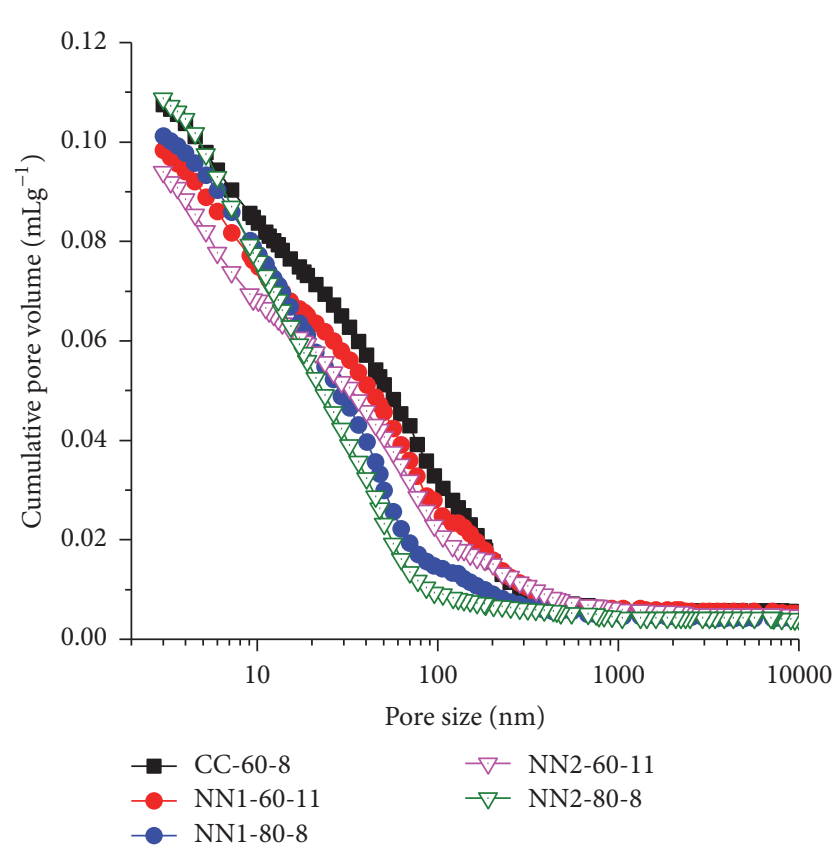

FIGURE 15: Pore structures of the steam-cured hardened paste with $\mathrm{W} / \mathrm{B}$ of 0.32 at the age of $90 \mathrm{~d}$.

is also the least, and the proportion of pores smaller than $20 \mathrm{~nm}$ of the hardened paste containing phosphorus slag under the steam curing of $80^{\circ} \mathrm{C}$ for $8 \mathrm{~h}$ is higher than that under the steam curing of $60^{\circ} \mathrm{C}$ for $11 \mathrm{~h}$. This indicates that elevated curing temperature tends to refine the late-age pore structure of the hardened paste containing phosphorus slag more effectively than extended steam curing duration.

In conclusion, the paste containing phosphorus slag can achieve denser pore structure than the plain cement paste

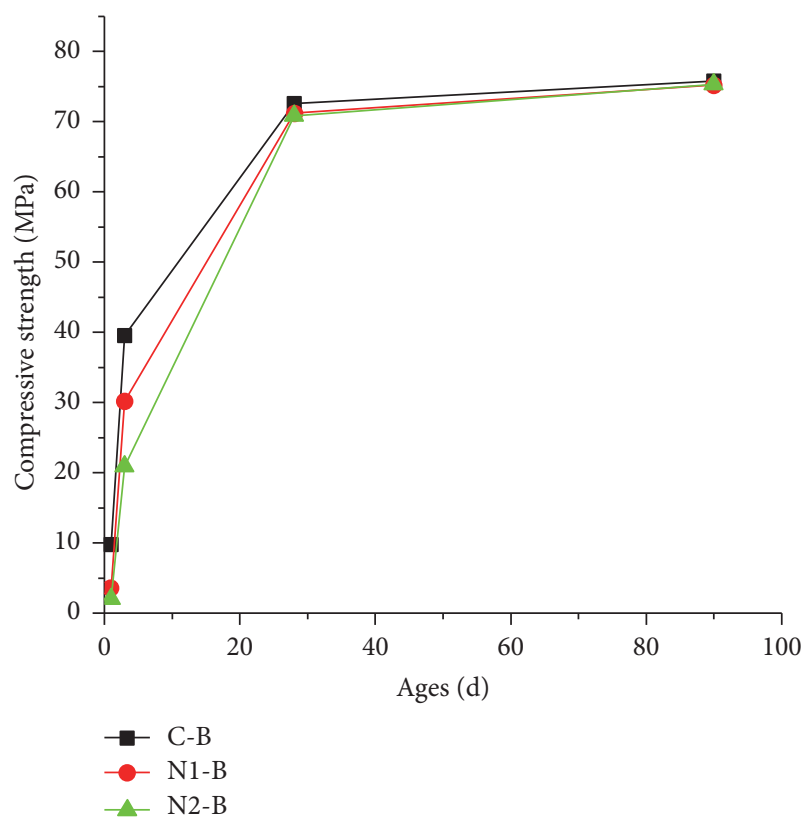

FIGURE 16: Compressive strength of the standard-cured concrete with W/B of 0.4 .

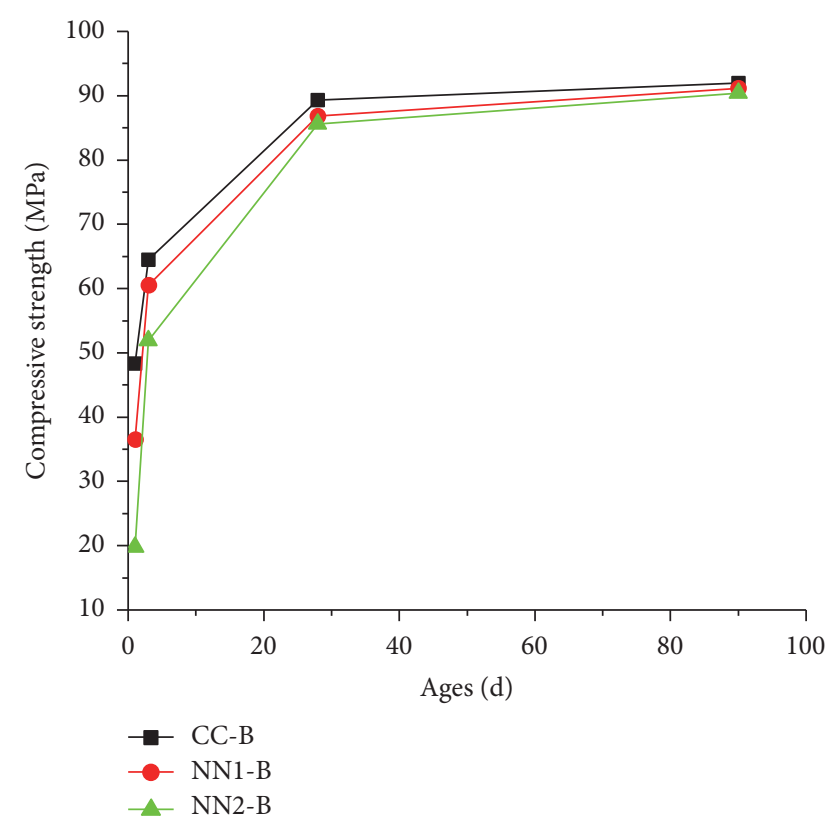

FIGURE 17: Compressive strength of the standard-cured concrete with W/B of 0.32 .

at the late ages by elevating steam curing temperature or extending steam curing duration. The late-age pore structure of the hardened paste containing phosphorus slag under the condition of elevating curing temperature is finer than that under the condition of extending steam curing duration, which corresponds to the trends of nonevaporable water content results.

3.5. Compressive Strength. Figures 16 and 17 show the compressive strength of standard-cured concrete with the W/B 


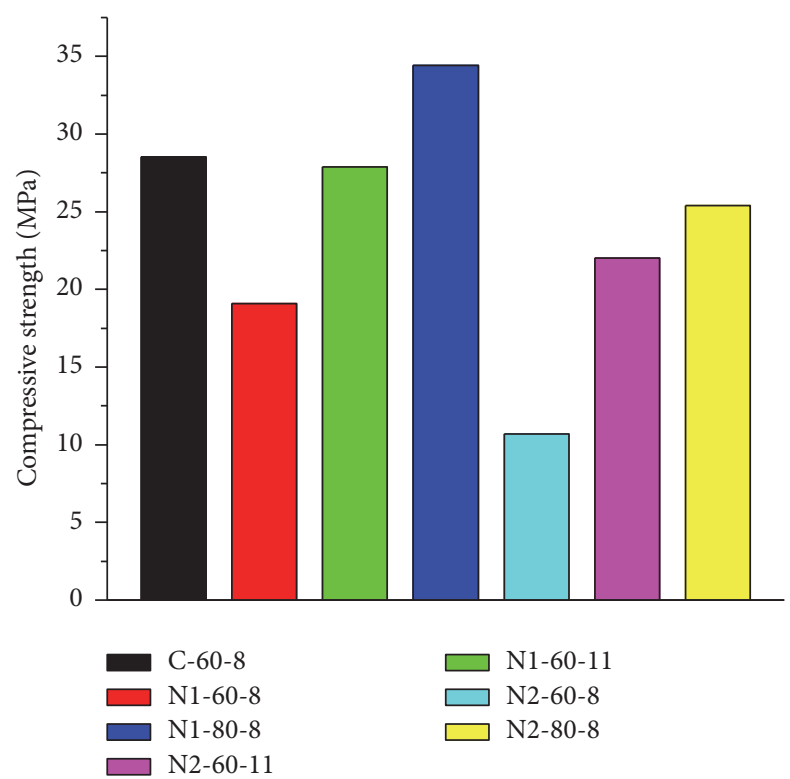

FIGURE 18: Demoulding strength of the steam-cured concrete with $\mathrm{W} / \mathrm{B}$ of 0.4 .

of 0.4 and 0.32 , respectively. Due to the retarding effect of phosphorus slag on the early hydration of cement, the early strength of concrete decreases with the increase of phosphorus slag replacement. For concrete with W/B of 0.4, the compressive strengths of the concrete containing phosphorus slag achieve less than $4 \mathrm{MPa}$ at the age of $18 \mathrm{~h}$. Even at the age of $3 \mathrm{~d}$, the compressive strengths of the concrete containing $15 \%$ and $30 \%$ phosphorus slag are $23.5 \%$ and $47.1 \%$ lower than that of plain cement concrete, respectively. However, the compressive strength of the concrete containing phosphorus slag is very close to that of the plain cement concrete at the late ages. Additionally, the growth rate of compressive strength of the concrete containing 30\% phosphorus slag is significantly higher than that of plain cement concrete as well as the concrete containing $15 \%$ phosphorus slag at late ages. For concrete with $\mathrm{W} / \mathrm{B}$ of 0.32 , the trends are basically the same as those of the concrete with W/B of 0.4. The addition of phosphorus slag tends to decrease the early strength but enhance the strength development at the late ages. Note that the addition of phosphorus slag tends to improve the lateage pore structure of hardened paste (Figures 12 and 13). In summary, though phosphorus slag has an adverse effect on the early hardening rate of concrete, it makes considerable contribution to the late strength development: the reaction degree of phosphorus slag increases at late ages which produces secondary C-S-H and consumes $\mathrm{Ca}(\mathrm{OH})_{2}[26]$, filling pores and improving the microstructure of interfacial transition zone of concrete.

Figures 18 and 19 show the demoulding strength of steamcured concrete with the $\mathrm{W} / \mathrm{C}$ of 0.4 and 0.32 , respectively. The plain cement concrete cured at $60^{\circ} \mathrm{C}$ for $8 \mathrm{~h}$ is employed as the control group. It is clear that the demoulding strength of the concrete decreases significantly with the increase of the phosphorus slag replacement ratio if the temperature and the duration of the steam curing condition remain unchanged,

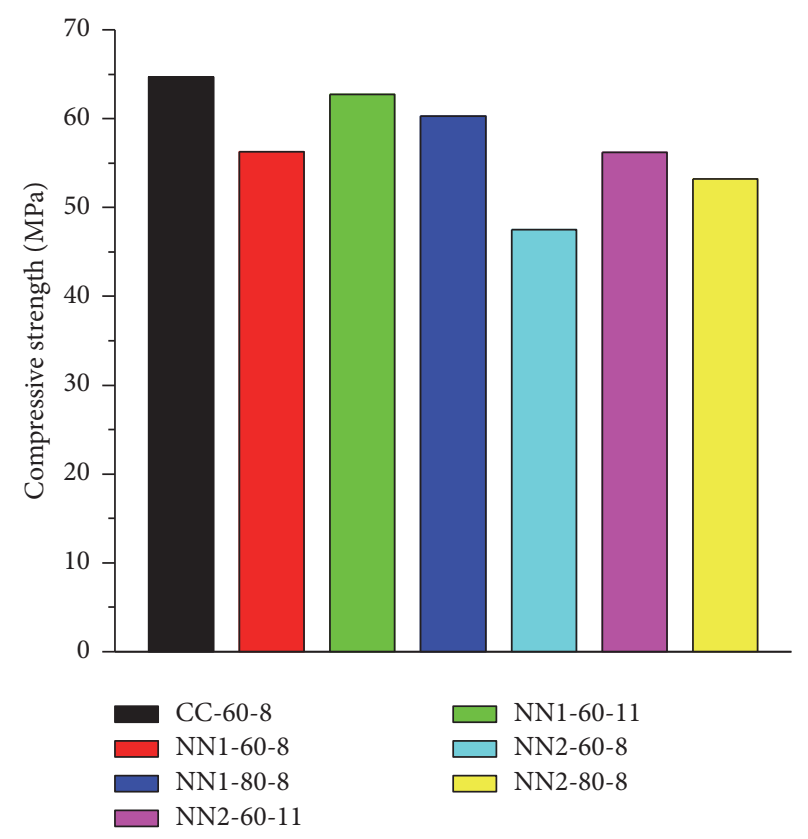

FIGURE 19: Demoulding strength of the steam-cured concrete with $\mathrm{W} / \mathrm{B}$ of 0.32 .

as a result of which the production of precast concrete cannot be carried out properly. As expected, the demoulding strength of the concrete containing phosphorus slag increases significantly with an extended steam curing duration to $11 \mathrm{~h}$ at $60^{\circ} \mathrm{C}$ or an elevated steam curing temperature at $80^{\circ} \mathrm{C}$ for $8 \mathrm{~h}$. As shown in Figure 18, elevated steam curing temperature tends to enhance the demoulding strength of the concrete containing phosphorus slag more obviously than extended steam curing duration at the $\mathrm{W} / \mathrm{B}$ of 0.4 . This result is consistent with the $w_{n}$ content result and hydration heat result: elevated steam curing temperature tends to increase the hydration degree of the binder containing phosphorus slag at demoulding time more obviously than extended steam curing duration at the W/B of 0.4. However, elevated steam curing temperature and extended steam curing duration have the similar enhancing effect on the demoulding strength of the concrete containing phosphorus slag at the $\mathrm{W} / \mathrm{B}$ of 0.32 (Figure 19). This may be because the influence degree of a small increment of hydration products on the compressive strength of concrete is very limited at such a low W/B.

Figures 20 and 21 show the compressive strengths at the ages of 3,7 , and $90 \mathrm{~d}$ of steam-cured concrete with the $\mathrm{W} / \mathrm{C}$ of 0.4 and 0.32 , respectively. It is obvious that the compressive strength of the concrete containing phosphorus slag is lower than that of control concrete at the age of $3 \mathrm{~d}$, no matter under the steam curing condition of $60^{\circ} \mathrm{C}$ for $11 \mathrm{~h}$ or $80^{\circ} \mathrm{C}$ for $8 \mathrm{~h}$. It is an indication that though the demoulding strength of the concrete containing phosphorus slag is close to that of the control concrete, the hydration rate of the binder containing phosphorus slag is lower than that of plain cement during the period from demoulding time to $3 \mathrm{~d}$. However, it is noteworthy that, with the increase of age, the compressive strength of the concrete containing phosphorus slag under the steam curing condition of $60^{\circ} \mathrm{C}$ for 


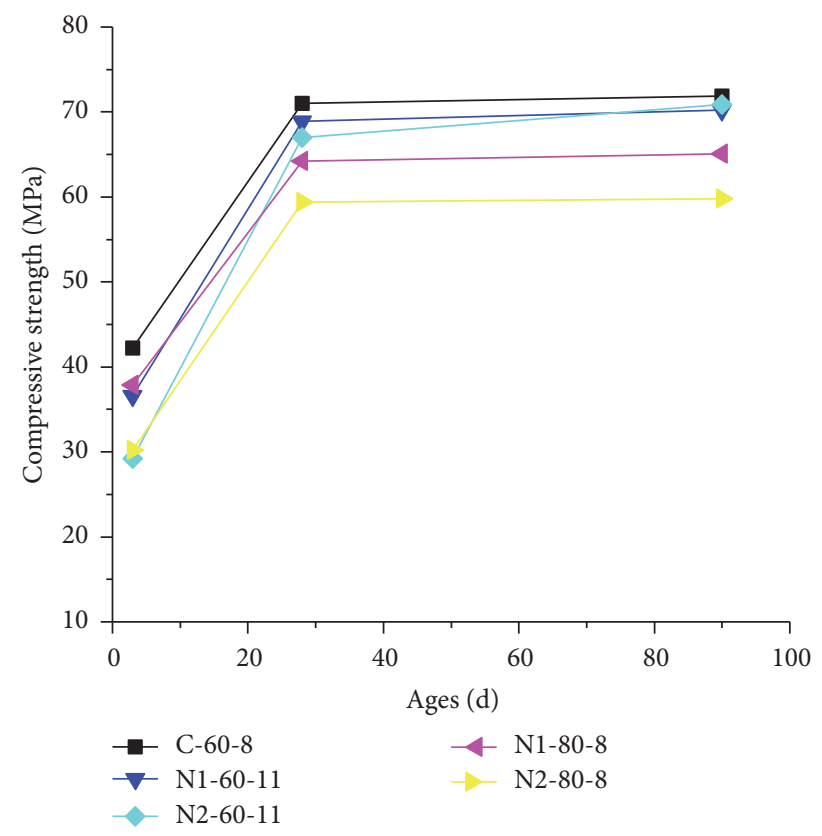

FIGURE 20: Compressive strength of the steam-cured concrete with $\mathrm{W} / \mathrm{B}$ of 0.4 .

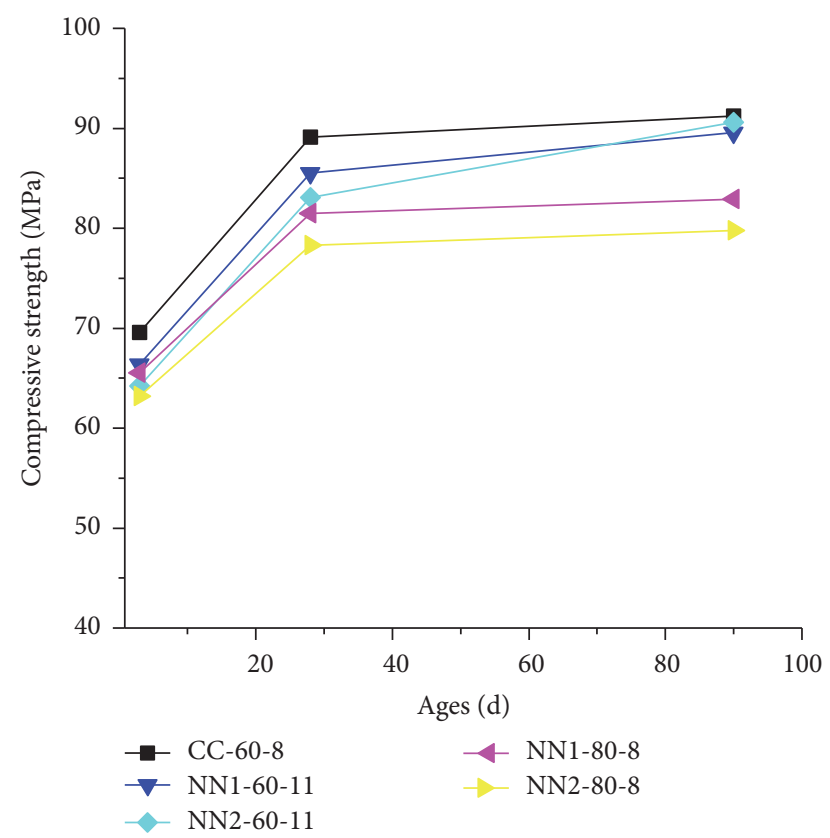

FIGURE 21: Compressive strength of the steam-cured concrete with $\mathrm{W} / \mathrm{B}$ of 0.32 .

$11 \mathrm{~h}$ is close to that of control concrete at late ages, while the compressive strength of the concrete containing phosphorus slag under the steam curing condition of $80^{\circ} \mathrm{C}$ for $8 \mathrm{~h}$ is significantly lower than that of control concrete. This result is not consistent with the MIP result (Figures 14 and 15) which indicates that elevated curing temperature improves the late-age pore structure of hardened paste more obviously than extended steam curing duration. It is believed that

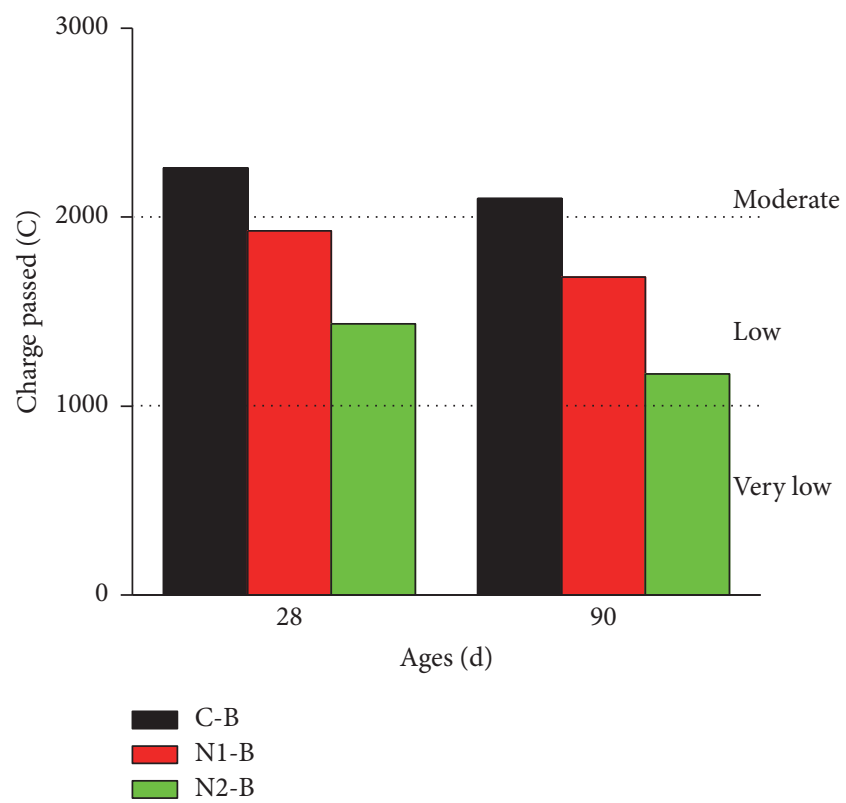

FIGURE 22: Chloride ion permeability of the standard-cured concrete with $\mathrm{W} / \mathrm{B}$ of 0.40 .

this difference is caused by the interfacial transition zone of concrete. Though elevated curing temperature improves the late-age pore structure of hardened paste, it has a significant adverse effect on the interfacial transition zone between hardened paste and aggregates, resulting in the decrease of compressive strength of concrete. Many researches have proved that elevated temperature curing at early ages has negative effects on the hydration of binder and the properties of concrete at late ages $[18,44]$. The results of Figures 20 and 21 further confirm that the negative effect of elevated temperature curing on the late strength of concrete is still so obvious when the temperature is raised from $60^{\circ} \mathrm{C}$ to $80^{\circ} \mathrm{C}$.

3.6. Chloride Ion Permeability. Figures 22 and 23 show the charge passed and the chloride ion permeability grade of standard-cured concrete at $28 \mathrm{~d}$ and $90 \mathrm{~d}$ with the W/C of 0.4 and 0.32, respectively. According to ASTM C1202, the chloride ion permeability grade of concrete is "very low" if the charge passed is between 100 and 1000 coulombs, and the grade is "low" or "moderate" if the charge passed is between 1000 and 2000 or between 2000 and 4000, respectively. As shown in Figure 22, the charge passed of the concrete with the W/C of 0.4 decreases with the increase of the phosphorus slag replacement ratio. The chloride ion permeability grade of concrete containing phosphorus slag at $28 \mathrm{~d}$ and $90 \mathrm{~d}$ decreases by one level compared with that of the plain concrete, which indicates that the resistance to chloride ion penetration of concrete is significantly enhanced by the addition of phosphorus slag. As shown in Figure 23, the charge passed of concrete with the $\mathrm{W} / \mathrm{C}$ of 0.32 also decreases with the increase of the phosphorus slag replacement ratio. However, the matrix of the plain cement concrete with the $\mathrm{W} / \mathrm{C}$ of 0.32 is already compact. Therefore, at such a low $\mathrm{W} / \mathrm{B}$, though the addition of phosphorus slag tends to reduce the 


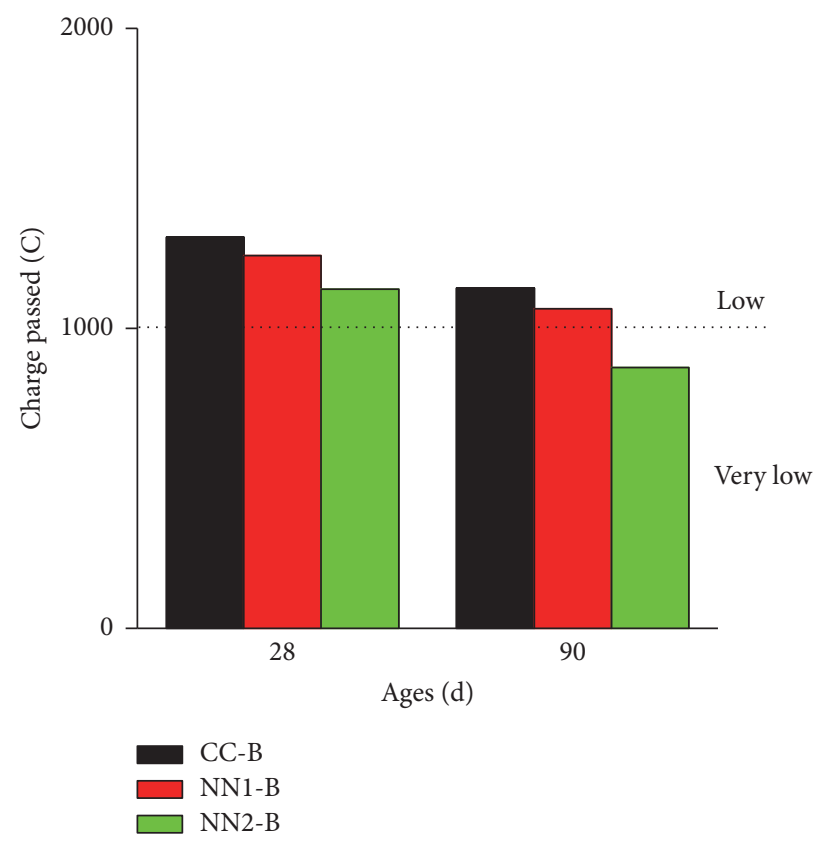

FIGURE 23: Chloride ion permeability of the standard-cured concrete with $\mathrm{W} / \mathrm{B}$ of 0.32 .

charge passed of the concrete, its influence on the chloride ion permeability grade is limited. The chloride ion permeability of concrete decreases by one level only when the phosphorus slag replacement ratio is $30 \%$ compared with that of the control concrete at the age of $90 \mathrm{~d}$. On the whole, the addition of phosphorus slag can improve the microstructure and the resistance to chloride ion penetration of concrete in some cases.

Figure 24 shows the charge passed and the chloride ion permeability grade of steam-cured concrete at $28 \mathrm{~d}$ and $90 \mathrm{~d}$ with the W/C of 0.4 . Whether at $28 \mathrm{~d}$ or $90 \mathrm{~d}$, the chloride ion permeability grade of the control concrete is "moderate," and the chloride ion permeability grade of the concrete containing phosphorus slag cured at $60^{\circ} \mathrm{C}$ for $11 \mathrm{~h}$ is "low," which indicates that extending the duration of steam curing at $60^{\circ} \mathrm{C}$ can ensure that the concrete obtains a satisfactory resistance to chloride ion penetration. However, when the steam curing temperature is elevated to $80^{\circ} \mathrm{C}$, the concrete containing phosphorus slag exhibits the same chloride ion permeability grade with the control concrete, except the concrete containing $30 \%$ phosphorus slag at the age of $90 \mathrm{~d}$, which indicates that elevated steam curing temperature has a negative effect on the resistance to chloride ion penetration of concrete.

Figure 25 shows the charge passed and the chloride ion permeability grade of steam-cured concrete at $28 \mathrm{~d}$ and $90 \mathrm{~d}$ with the W/C of 0.32 . Whether at $28 \mathrm{~d}$ or $90 \mathrm{~d}$, the charge passed of the concrete containing phosphorus slag cured at $60^{\circ} \mathrm{C}$ for $11 \mathrm{~h}$ decreases compared with that of the control concrete, while the chloride ion permeability grade of the concrete containing phosphorus slag is the same with that of the control concrete. The charge passed of the concrete containing phosphorus slag cured at $80^{\circ} \mathrm{C}$ for $8 \mathrm{~h}$

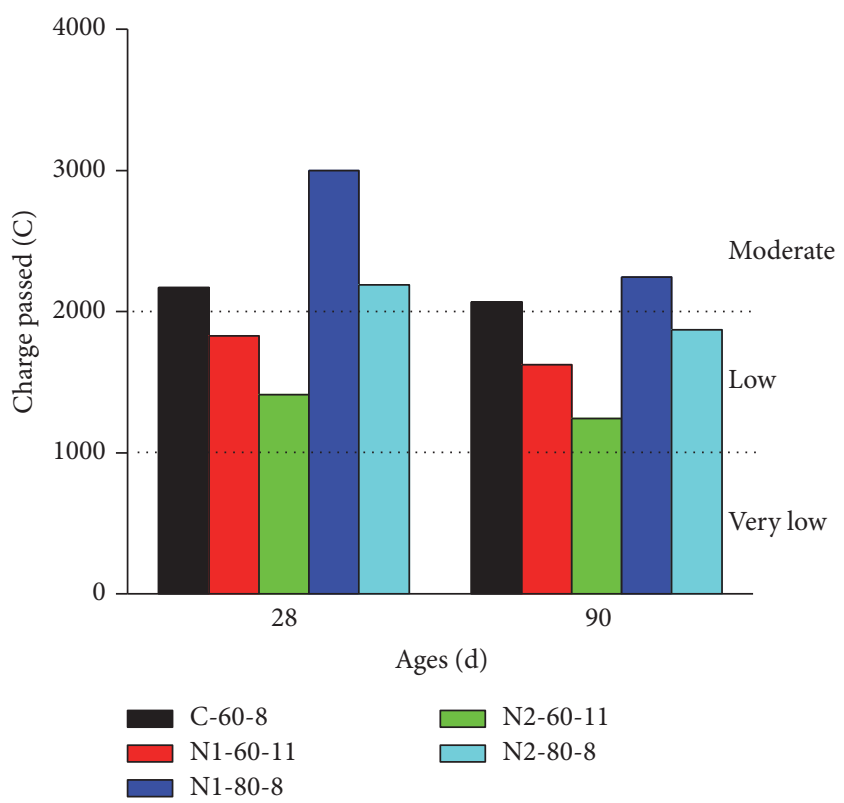

FIGURE 24: Chloride ion permeability of the steam-cured concrete with $\mathrm{W} / \mathrm{B}$ of 0.40 .

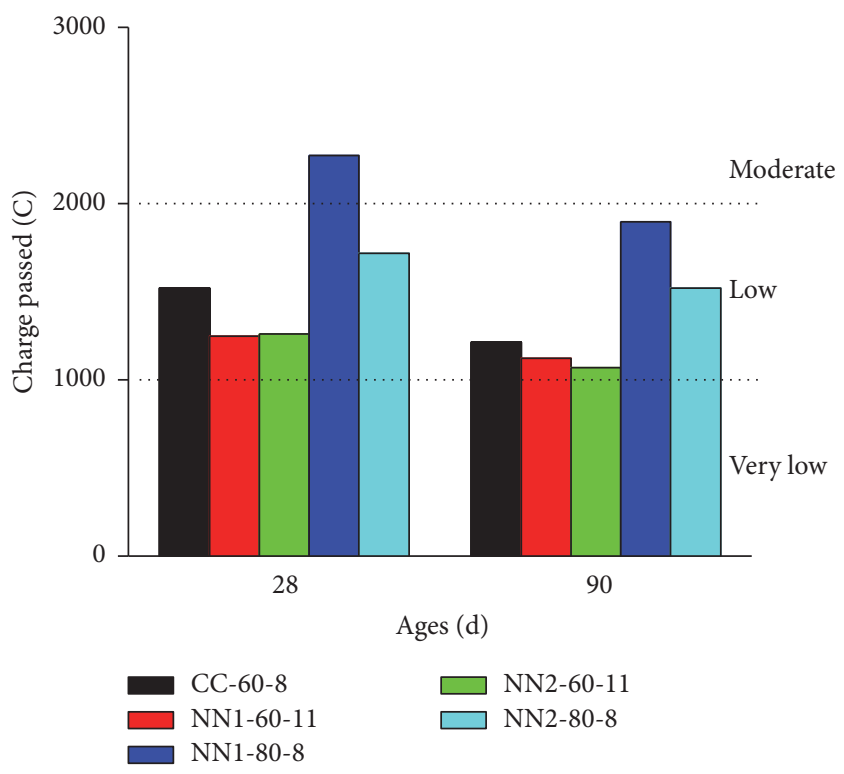

FIGURE 25: Chloride ion permeability of the steam-cured concrete with $\mathrm{W} / \mathrm{B}$ of 0.32 .

increases compared with that of the control concrete, and the chloride ion permeability grade of the concrete containing $15 \%$ phosphorus slag increases by one level at the age of $28 \mathrm{~d}$. On the whole, when the curing temperature is increased from $60^{\circ} \mathrm{C}$ to $80^{\circ} \mathrm{C}$, it tends to reduce the resistance of concrete to chloride ion penetration at certain circumstance.

In conclusion, the addition of phosphorus slag has positive effects on the late-age microstructure and the resistance to chloride ion penetration of concrete under the steam curing condition of $60^{\circ} \mathrm{C}$. However, the resistance to chloride 
ion penetration of concrete containing phosphorus slag under the steam curing condition of $80^{\circ} \mathrm{C}$ is close to or even worse than the plain concrete, which might be due to the significant adverse effect of elevated curing temperature on the microstructure of interfacial transition zone of concrete.

\section{Discussion}

The demoulding strength of steam-cured concrete needs to be ensured in the first place. Under the condition of normal curing temperature, the addition of phosphorus slag would reduce the early strength of concrete significantly. Though elevated curing temperature tends to promote the early hydration of the composite binder containing phosphorus slag significantly, the concrete containing phosphorus slag cannot achieve similar demoulding strength with the plain cement concrete in the case of the same steam curing temperature and duration time. The demoulding strength results indicate that elevated steam curing temperature is more effective than extended steam curing duration, which is consistent with the trends of hydration heat results and nonevaporable water content results.

The MIP results indicate that the addition of phosphorus slag can improve the late-age pore structure of hardened paste whether cured at normal temperature or elevated temperature. Moreover, the late-age pore structure of hardened paste containing phosphorus slag cured at $80^{\circ} \mathrm{C}$ for $8 \mathrm{~h}$ is finer than that cured at $60^{\circ} \mathrm{C}$ for $11 \mathrm{~h}$, and this trend is consistent with the trend of nonevaporable water content results. However, besides pore structure of hardened paste, the interfacial transition zone between matrix and aggregate is consistent with compressive strength and chloride ion permeability. It is notable that the effects of curing method on the properties of hardened paste and concrete might vary significantly due to the interfacial transition zone. The results of this paper show that the steam-cured concrete containing phosphorus slag cured at $60^{\circ} \mathrm{C}$ for $11 \mathrm{~h}$ can achieve higher late-age compressive strength and lower chloride permeability than that cured at $80^{\circ} \mathrm{C}$ for $8 \mathrm{~h}$. Therefore, considering both demolding strength and late-age proprieties, extending the steam curing duration is a preferred method for the concrete containing phosphorus slag.

\section{Conclusions}

(1) Elevated steam curing temperature promotes the early hydration of the binder containing phosphorus slag more obviously than extended steam curing duration; moreover, the former method also results in higher late-age hydration degree of binder and finer pore structure of hardened paste.

(2) For steam-cured concrete containing phosphorus slag, the late-age strength decreases and the chloride permeability increases by increasing the curing temperature from $60^{\circ} \mathrm{C}$ to $80^{\circ} \mathrm{C}$. The positive effects of phosphorus slag on the late-age properties of concrete are not well performed. The steam-cured temperature of $80^{\circ} \mathrm{C}$ is not suitable for steam-cured concrete containing phosphorus.

(3) The steam-cured concrete containing phosphorus slag can achieve satisfied demoulding strength and late-age strength and chloride permeability by extending the steam curing duration at constant curing temperature of $60^{\circ} \mathrm{C}$.

\section{Conflicts of Interest}

The authors declare that there are no conflicts of interest regarding the publication of this paper.

\section{Acknowledgments}

The support of China National Natural Science Foundation Project (no. 51572293) is acknowledged.

\section{References}

[1] M. Kim, Q. Wang, J. Park, J. C. Cheng, H. Sohn, and C. Chang, "Automated dimensional quality assurance of full-scale precast concrete elements using laser scanning and BIM," Automation in Construction, vol. 72, pp. 102-114, 2016.

[2] Q. Wang, M. Kim, S. Yoon, J. C. Cheng, and H. Sohn, "Corrigendum to "Automated quality assessment of precast concrete elements with geometry irregularities using terrestrial laser scanning" [Autom. Constr. 68 (2016) 170-182]," Automation in Construction, vol. 74, p. 1, 2016.

[3] M.-K. Kim, J. C. P. Cheng, H. Sohn, and C.-C. Chang, "A framework for dimensional and surface quality assessment of precast concrete elements using BIM and 3D laser scanning," Automation in Construction, vol. 49, pp. 225-238, 2015.

[4] J. Choi, S.-K. Park, H.-Y. Kim, and S. Hong, "Behavior of high-performance mortar and concrete connections in precast concrete elements: experimental investigation under static and cyclic loadings," Engineering Structures, vol. 100, pp. 633-644, 2015.

[5] Q. Wang, M. Li, and B. Zhang, "Influence of pre-curing time on the hydration of binder and the properties of concrete under steam curing condition," Journal of Thermal Analysis and Calorimetry, vol. 118, no. 3, pp. 1505-1512, 2014.

[6] G. Long, M. Wang, Y. Xie, and K. Ma, "Experimental investigation on dynamic mechanical characteristics and microstructure of steam-cured concrete," Science China Technological Sciences, vol. 57, no. 10, pp. 1902-1908, 2014.

[7] A. Gonzalez-Corominas, M. Etxeberria, and C. S. Poon, "Influence of steam curing on the pore structures and mechanical properties of fly-ash high performance concrete prepared with recycled aggregates," Cement and Concrete Composites, vol. 71, pp. 77-84, 2016.

[8] F. Cassagnabère, G. Escadeillas, and M. Mouret, "Study of the reactivity of cement/metakaolin binders at early age for specific use in steam cured precast concrete," Construction and Building Materials, vol. 23, no. 2, pp. 775-784, 2009.

[9] M. Gesoğlu, "Influence of steam curing on the properties of concretes incorporating metakaolin and silica fume," Materials and Structures, vol. 43, no. 8, pp. 1123-1134, 2010. 
[10] D. W. S. Ho, C. W. Chua, and C. T. Tam, "Steam-cured concrete incorporating mineral admixtures," Cement and Concrete Research, vol. 33, no. 4, pp. 595-601, 2003.

[11] E. Gallucci, X. Zhang, and K. L. Scrivener, "Effect of temperature on the microstructure of calcium silicate hydrate (C-S-H)," Cement and Concrete Research, vol. 53, no. 2, pp. 185-195, 2013.

[12] A. M. Ramezanianpour, K. Esmaeili, S. A. Ghahari, and A. A. Ramezanianpour, "Influence of initial steam curing and different types of mineral additives on mechanical and durability properties of self-compacting concrete," Construction and Building Materials, vol. 73, pp. 187-194, 2014.

[13] C. Gu, W. Sun, L. Guo, and Q. Wang, "Effect of curing conditions on the durability of ultra-high performance concrete under flexural load," Journal Wuhan University of Technology, Materials Science Edition, vol. 31, no. 2, pp. 278-285, 2016.

[14] A. C. Aydin, A. Öz, R. Polat, and H. Mindivan, "Effects of the different atmospheric steam curing processes on the properties of self-compacting-concrete containing microsilica," Sadhana Academy Proceedings in Engineering Sciences, vol. 40, no. 4, pp. 1361-1371, 2015.

[15] F. Sajedi and H. A. Razak, "Effects of curing regimes and cement fineness on the compressive strength of ordinary Portland cement mortars," Construction and Building Materials, vol. 25, no. 4, pp. 2036-2045, 2011.

[16] S. J. Barnett, M. N. Soutsos, S. G. Millard, and J. H. Bungey, "Strength development of mortars containing ground granulated blast-furnace slag: Effect of curing temperature and determination of apparent activation energies," Cement and Concrete Research, vol. 36, no. 3, pp. 434-440, 2006.

[17] S. Martínez-Ramírez and M. Frías, "The effect of curing temperature on white cement hydration," Construction and Building Materials, vol. 23, no. 3, pp. 1344-1348, 2009.

[18] Q. Wang, M. Miao, J. Feng, and P. Yan, "The influence of hightemperature curing on the hydration characteristics of a cement-GGBS binder," Advances in Cement Research, vol. 24, no. 1, pp. 33-40, 2012.

[19] S. Mengxiao, W. Qiang, and Z. Zhikai, "Comparison of the properties between high-volume fly ash concrete and highvolume steel slag concrete under temperature matching curing condition," Construction and Building Materials, vol. 98, pp. 649-655, 2015.

[20] H. Fanghui, W. Qiang, L. Mutian, and M. Yingjun, "Early hydration properties of composite binder containing limestone powder with different finenesses," Journal of Thermal Analysis and Calorimetry, vol. 123, no. 2, pp. 1141-1151, 2016.

[21] T. Zhang, Q. Yu, J. Wei, and J. Li, "Investigation on mechanical properties, durability and micro-structural development of steel slag blended cements," Journal of Thermal Analysis and Calorimetry, vol. 110, no. 2, pp. 633-639, 2012.

[22] G. Qian, S. Bai, S. Ju, and T. Huang, "Laboratory evaluation on recycling waste phosphorus slag as the mineral filler in hot-mix asphalt," Journal of Materials in Civil Engineering, vol. 25, no. 7, pp. 846-850, 2013.

[23] X.-W. Liu, L. Yang, and B. Zhang, "Utilization of phosphorus slag and fly ash for the preparation of ready-mixed mortar," Applied Mechanics and Materials, vol. 423-426, pp. 987-992, 2013.

[24] Y. Peng, J. Zhang, J. Liu, J. Ke, and F. Wang, "Properties and microstructure of reactive powder concrete having a high content of phosphorous slag powder and silica fume," Construction and Building Materials, vol. 101, pp. 482-487, 2015.
[25] C. Shi and J. Qian, "High performance cementing materials from industrial slags-a review," Resources, Conservation and Recycling, vol. 29, no. 3, pp. 195-207, 2000.

[26] P. Gao, X. Lu, C. Yang, X. Li, N. Shi, and S. Jin, "Microstructure and pore structure of concrete mixed with superfine phosphorous slag and superplasticizer," Construction and Building Materials, vol. 22, no. 5, pp. 837-840, 2008.

[27] X. Chen, L. Zeng, and K. Fang, "Anti-crack performance of phosphorus slag concrete," Wuhan University Journal of Natural Sciences, vol. 14, no. 1, pp. 80-86, 2009.

[28] L. Kalina, V. Bílek, R. Novotný, M. Mončeková, J. Másilko, and J. Koplík, "Effect of Na3PO4 on the hydration process of alkaliactivated blast furnace slag," Materials, vol. 9, no. 5, article 395, 2016.

[29] X. Chen, K. H. Fang, H. Q. Yang, and H. Peng, "Hydration kinetics of phosphorus slag-cement paste," Journal Wuhan University of Technology, Materials Science Edition, vol. 26, no. 1, pp. 142-146, 2011.

[30] L. Dong-xu, C. Lin, X. Zhong-zi, and L. Zhi-min, "A blended cement containing blast furnace slag and phosphorous slag," Journal of Wuhan University of Technology-Mater. Sci. Ed., vol. 17, no. 2, pp. 62-65, 2002.

[31] J. Feng, S. Liu, and Z. Wang, "Effects of ultrafine fly ash on the properties of high-strength concrete," Journal of Thermal Analysis and Calorimetry, vol. 121, no. 3, pp. 1213-1223, 2015.

[32] S. W. Tang, X. H. Cai, Z. He, H. Y. Shao, Z. J. Li, and E. Chen, "Hydration process of fly ash blended cement pastes by impedance measurement," Construction and Building Materials, vol. 113, pp. 939-950, 2016.

[33] S. K. Rao, P. Sravana, and T. C. Rao, "Abrasion resistance and mechanical properties of Roller Compacted Concrete with GGBS," Construction and Building Materials, vol. 114, pp. 925933, 2016.

[34] G. D. Moon, S. Oh, and Y. C. Choi, "Effects of the physicochemical properties of fly ash on the compressive strength of highvolume fly ash mortar," Construction and Building Materials, vol. 124, pp. 1072-1080, 2016.

[35] M.-F. Ba, C.-X. Qian, X.-J. Guo, and X.-Y. Han, "Effects of steam curing on strength and porous structure of concrete with low water/binder ratio," Construction and Building Materials, vol. 25, no. 1, pp. 123-128, 2011.

[36] Y. Zhang, W. Zhang, W. She, L. Ma, and W. Zhu, "Ultrasound monitoring of setting and hardening process of ultra-high performance cementitious materials," NDT and E International, vol. 47, pp. 177-184, 2012.

[37] Q. Wang, M. Li, and G. Jiang, "The difference among the effects of high-temperature curing on the early hydration properties of different cementitious systems," Journal of Thermal Analysis and Calorimetry, vol. 118, no. 1, pp. 51-58, 2014.

[38] M.-F. Ba and C.-X. Qian, "Hydration evolution of pre-cast concrete with steam and water curing," Journal of Central South University, vol. 20, no. 10, pp. 2870-2878, 2013.

[39] Z. He, J. Liu, and K. Zhu, "Influence of mineral admixtures on the short and long-term performance of steam-cured concrete," in Proceedings of the International Conference on Future Energy, Environment, and Materials, FEEM 2012, pp. 836-841, China, April 2012.

[40] B. Lothenbach, F. Winnefeld, C. Alder, E. Wieland, and P. Lunk, "Effect of temperature on the pore solution, microstructure and hydration products of Portland cement pastes," Cement and Concrete Research, vol. 37, no. 4, pp. 483-491, 2007. 
[41] J.-K. Kim, S. H. Han, and Y. C. Song, "Effect of temperature and aging on the mechanical properties of concrete: part I. Experimental results," Cement and Concrete Research, vol. 32, no. 7, pp. 1087-1094, 2002.

[42] R. Sarita, N. B. Singh, and N. P. Singh, "Interaction of tartaric acid during hydration of Portland cement," Indian Journal of Chemical Technology, vol. 13, no. 5, pp. 255-261, 2006.

[43] M. S. Morsy, "Effect of temperature on electrical conductivity of blended cement pastes," Cement and Concrete Research, vol. 29, no. 4, pp. 603-606, 1999.

[44] Q. Wang, J. J. Feng, and P. Y. Yan, "An explanation for the negative effect of elevated temperature at early ages on the lateage strength of concrete," Journal of Materials Science, vol. 46, no. 22 , pp. 7279-7288, 2011. 

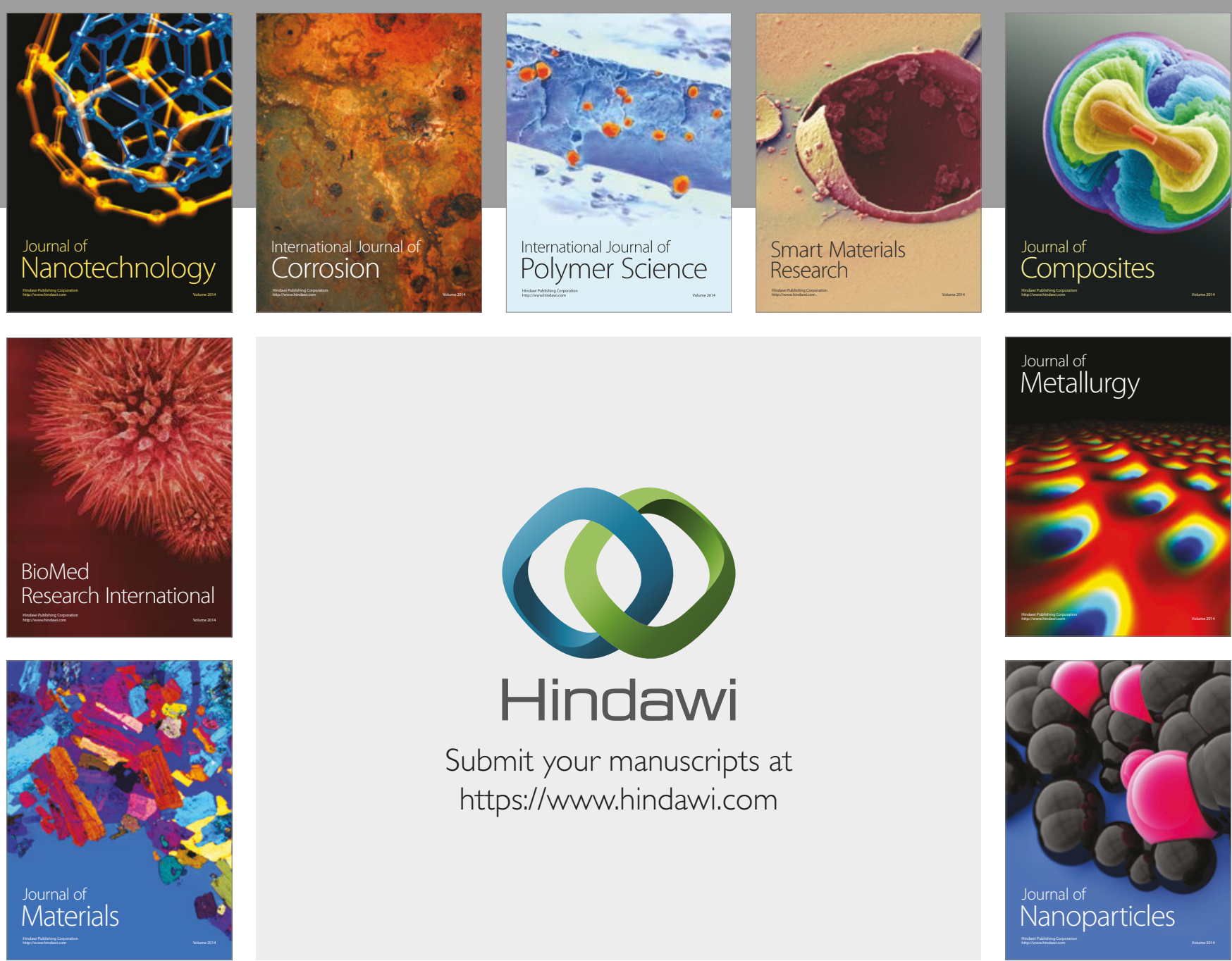

\section{Hindawi}

Submit your manuscripts at

https://www.hindawi.com
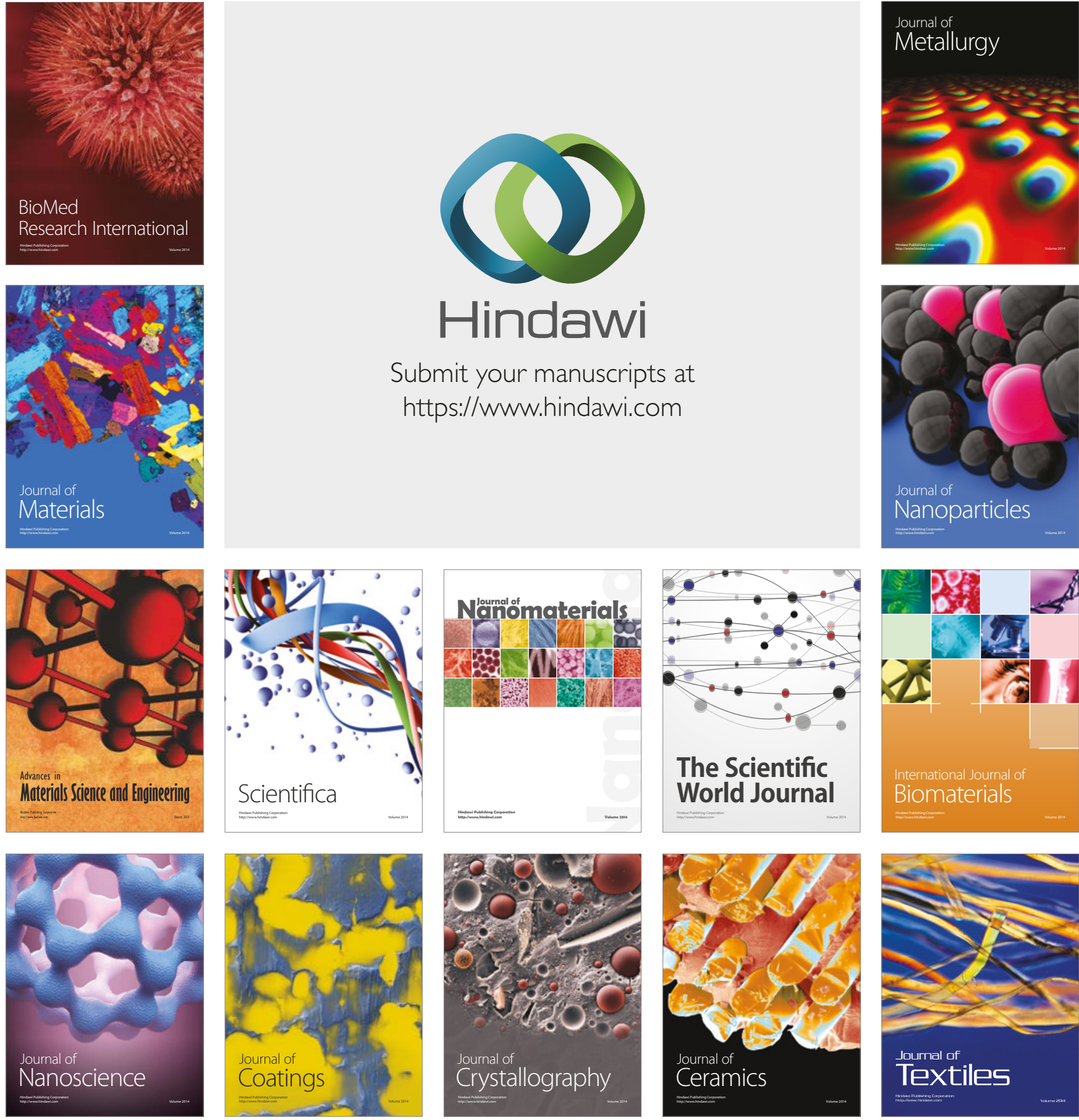

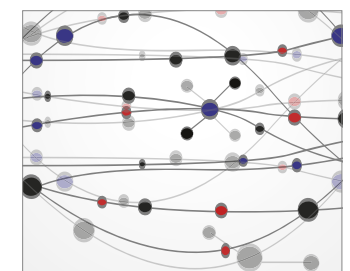

The Scientific World Journal
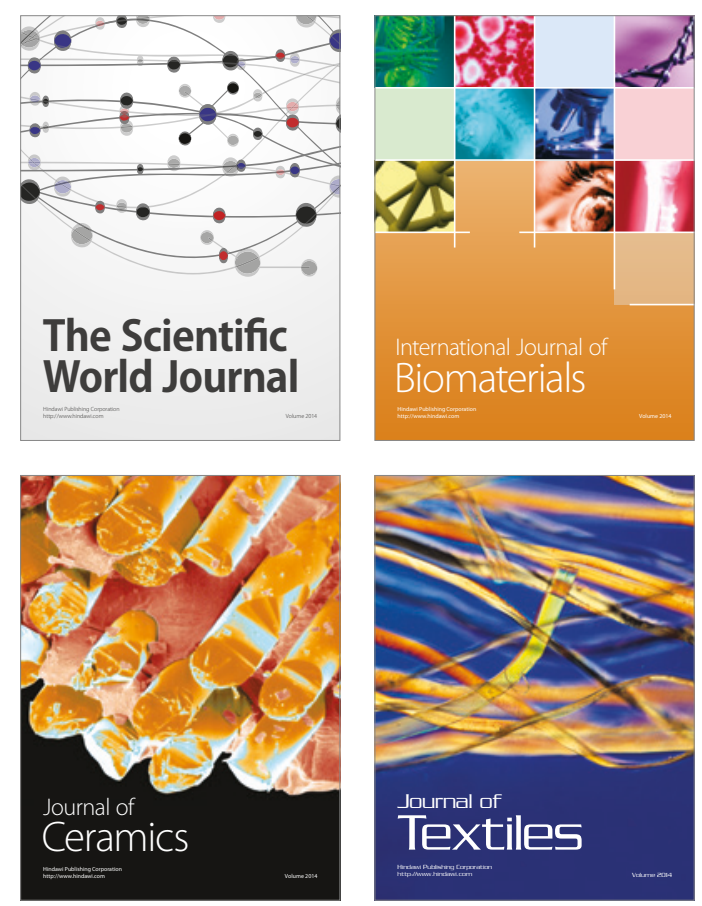